(C) 2020 by the Arizona Board of Regents on behalf of the University of Arizona. This is an Open Access article, distributed under the terms of the Creative Commons Attribution licence (http://creativecommons. org/licenses/by/4.0/), which permits unrestricted re-use, distribution, and reproduction in any medium, provided the original work is properly cited.

\title{
RADIOCARBON DATING THE 3RD MILLENNIUM BC IN THE CENTRAL BALKANS: A RE-EXAMINATION OF THE EARLY BRONZE AGE SEQUENCE
}

\author{
Aleksandar Bulatović ${ }^{1}$ - Maja Gori ${ }^{2 *}$ (D) Marc Vander Linden ${ }^{3}$ (D) \\ ${ }^{1}$ Institute of Archaeology, Belgrade - Prehistory, Kneza Mihaila 35/IV, Belgrade 11000, Serbia \\ ${ }^{2}$ ISPC-CNR, Institute of Heritage Science - National Research Council, Rome, Italy \\ ${ }^{3}$ Department of Archaeology and Anthropology, Bournemouth University, Bournemouth, UK
}

\begin{abstract}
Long-standing archaeological narratives suggest that the 3 rd millennium cal BC is a key period in Mediterranean and European prehistory, characterized by the development of extensive interaction networks. In the Balkans for instance, the identification of such interactions relies solely upon typological arguments associated with conflicting local terminologies. Through a combination of 25 new radiocarbon $\left({ }^{14} \mathrm{C}\right)$ dates and re-examination of the existing documentation, this paper defines the absolute chronology for groups which were previously only broadly framed into the 3rd millennium BC central Balkans (modern-day Serbia and North Macedonia). These absolute dates allow us to establish with greater clarity the chronological relations between different cultural groups that represent the main cultural units of the central Balkans sequence for the 3rd millennium cal BC: Coţofeni-Kostolac, Bubanj-Hum II, Belotić-Bela Crkva, Armenochori, and Bubanj Hum III. When comparing together the chronologies for material culture, funerary treatment of the body, and funerary architecture, there are no easily discernible patterns. We observe instead a complex mix of traits criss-crossing over a wide area encompassing the Pannonian basin, the central Balkans and the Greek peninsula.
\end{abstract}

KEYWORDS: Balkans, Bayesian modeling, Early Bronze Age, radiocarbon AMS dating.

\section{INTRODUCTION}

The 3rd millennium cal BC-referred to as Late Eneolithic or Early Bronze Age in different local research traditions - is a key period in Mediterranean and European prehistory, during which major transformations took place as evidenced by the development of extensive interaction networks. In the Balkans, this process is materialized by a complex archaeological record where various traits and practices are distributed over extended areas linking together different cultural spheres with, on the one hand, the Aegean and the Eastern Mediterranean, and, on the other hand, the Carpathian Basin and Central Europe. For instance, two-handled beakers - vessels with a variety of morphologies with two high-swung vertical handles - appear in an area extending from Transdanubia to continental Greece during a period spanning the mid-3rd to early 2nd millennium BC (Garašanin 1983: 720-722; Stojić 1996: 248; Roman 2006: 459; Bulatović and Stankovski 2012: 323-326; Gori 2018: 399-404). Roughly at the same time, the Cetina phenomenon is defined by the presence of particular ceramic style and archaeological features from Dalmatia over the entire Adriatic-Ionian area during the second half of the 3rd millennium BC (Govedarica 1989; Forenbaher 2018a, 2018b). Further evidence from ceramic assemblages suggests also connections between these two groups (see below).

Although great emphasis has always been given to Mediterranean patterns of sea-borne connectivity (e.g. van Dommelen and Knapp 2010; Broodbank 2013), new data and analyses are increasingly demonstrating that overland connections were not only closely intertwined to maritime routes, but that they played a primary role in the development of 3rd millennium cal BC societies (e.g. Maran 1998; Gori 2020).

In the central Balkans, defined as the region comprising the central part of present-day Serbia (with the exclusion of Vojvodina, which lies in the southern Pannonian plain), the northern part

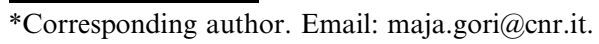


of North Macedonia, and western Bulgaria (Cvijić 1922), our ability to identify and trace such distant connections relies primarily upon intricate typological debates, associated with potentially circular arguments and confusing, conflicting local terminologies. For instance, despite differences in detailed sub-divisions, there is a general agreement that the Early Bronze Age in Bulgaria lies between the middle of the 4th and the end of the 3rd millennium cal BC (Leshtakov 1992; Nikolova 1999; Todorova 2003), and in continental Greece between 3100 and 2000 cal BC (Manning 1995; Rutter 2001; Wiencke 2000; Arvaniti and Maniatis 2018); yet, in Serbia the start of this period is traditionally placed at the end of the 3rd millennium cal BC, following Reinecke's chronology of the Central European Bronze Age (Reinecke 1902; Garašanin D. 1967). Whilst, in the first two areas, the chronological systems are internally coherent and based upon-admittedly limited-radiocarbon dates (e.g. Boyadziev 1995), they present noticeable discrepancies with Serbia, despite marked similarities in the archaeological record. The chronological position of the Early Bronze Age in Serbia has long been debated, with some scholars having complained that the general archaeological picture has changed very little in recent decades, especially when compared to neighbouring areas (e.g. Tasić and Tasić 2003: 98). This situation is particularly noticeable given the shortage of absolute chronological information (e.g. Krstić et al. 1986; Nikolova 1999: 404; Bogdanović 1986; Gogâltan 1999; Bulatović and Stankovski 2012), until the recent publication of some ${ }^{14} \mathrm{C}$ dates for the site of Bubanj (Bulatović and Vander Linden 2017).

Likewise in present Croatia and Albania there is an on-going debate concerning the chronological position of the Early Bronze Age, especially as concerns the extensive interaction networks that connect the western Balkans to the Aegean and southern Italy (i.e. the Cetina phenomenon) and the cultural groups that spread in the entire Macedonian region encompassing different chronological systems (i.e. Armenochori). To avoid confusion in this paper the entire 3rd millennium BC will be referred to as Early Bronze Age.

In order to fill this damaging documentary gap, we obtained 25 absolute dates for the end of the 4th and the 3rd millennium cal BC from a series of sites located in modern-day Serbia and North Macedonia (Figure 1). These include a combination of settlements-some of them with stratified deposits - and cemeteries (Table 1), as well as recent and older investigations. As much as possible, dates were obtained on bone samples (including cremations) originating from reliable stratigraphic contexts, demonstrating robust associations with either key ceramic types (e.g. double-handled beakers) or cultural practices (especially cremations), which are at the core of existing typo-cultural arguments for the period and area under consideration. After a brief presentation of the archaeological context of each site, we discuss the implications of our results for our understanding of the chronology of the Early Bronze Age in the central Balkans, and for the wider associated socio-cultural dynamics. In particular, we discuss the absolute chronology for Cotofeni-Kostolac, BelotićBela Crkva, Armenochori, and Bubanj Hum III groups, which represent the main cultural units of the central Balkans sequence for the 3rd millennium cal BC.

\section{ARCHAEOLOGICAL DATA}

\section{Stratified Settlements}

Bubanj is a stratified prehistoric settlement located in the middle course of the Južna Morava River, close to the confluence with the Nišava River, in the Niš plain, southeastern Serbia. The site was excavated on several occasions during the 1930s, 1950s, and lastly between 2008 and 2014 (Orsich-Slavetić 1940; Garašanin M. 1958a; Bulatović and Milanović 2020). During the 


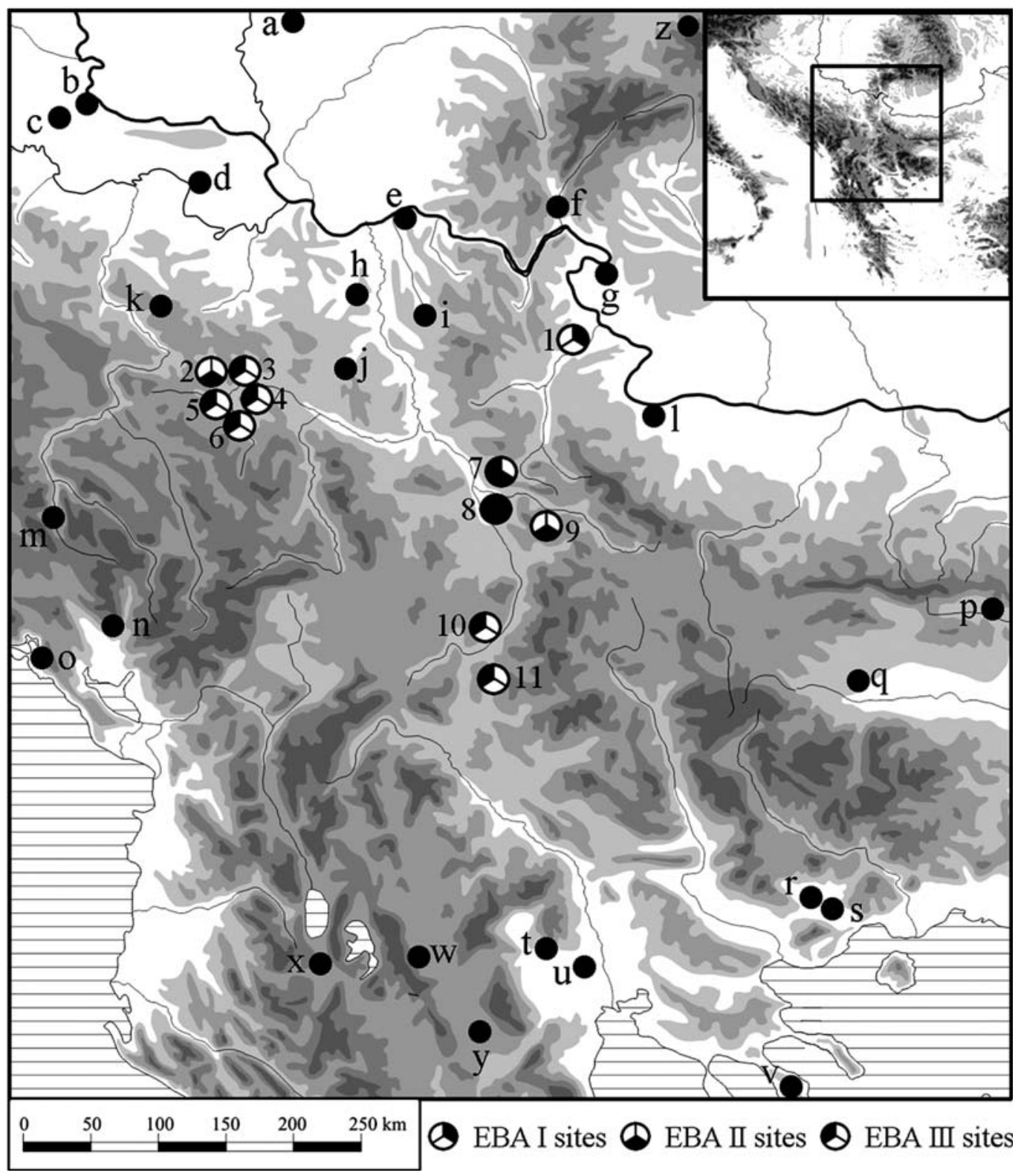

Figure 1 Sites mentioned in the study: 1. Mokranje, Mokranjske Stene; 2. Jančići, Veliko Polje; 3. Prijevor, Ade; 4. Dučalovići, Ruja; 5. Krstac, Ivkovo Brdo; 6. Lučani, Suva Česma; 7. Hum, Velika Humska Čuka; 8. Novo Selo, Bubanj; 9. Glogovac, Polje; 10. Ranutovac, Meanište; 11. Pelince, Dve Mogili. a. Mokrin, b. Vučedol, c. Vinkovci, d. Gomolava, e. Viminacijum, f. Baile Herculane, g. Ostrovul Corbului, h. Novačka Ćuprija, i. Belovode, j. Ljuljaci, k. Belotić and Bela Crkva, 1. Bagačina, m. Odmut, n. Gruda Boljevića, o. Velika Gruda and Mala Gruda, p. Dubene, q. Junacite, r. Sitagroi, s. Dikili Tash, t. Mandalo, u. Archontiko, v. Sykia, w. Armenochori, x. Sovjan, y. Xeropigado, z. Poiana Ampoiului.

last excavation campaigns numerous structures were uncovered, belonging to the Neolithic, Copper and Bronze Ages (Bulatović and Vander Linden 2017). One sample (MAMS-31462) was taken from below floor $82 \mathrm{~A}$, which possibly belongs to a pre-Cotgofeni-Kostolac horizon. 
Table 1 Absolute dates for the central Balkans EBA groups obtained in this study. The $\delta^{13} \mathrm{C}$ was obtained from the isotope determination in the AMS system, for collagen on uncremated bones, and on carbonate for cremated ones. This value may be influenced by isotope fractionation and is only used for fractionation correction. Hence, this value is not comparable to the one obtained in a stable isotope IRMS and should not be used for further data interpretation.

\begin{tabular}{|c|c|c|c|c|c|c|c|}
\hline Site & $\begin{array}{l}\text { N. on } \\
\text { map }\end{array}$ & Lab code & Context & Sample & $\mathrm{BP}$ & $\begin{array}{c}\delta^{13} \mathrm{C} \\
\% 0\end{array}$ & $\begin{array}{l}\text { Rel. } \\
\text { Chron. }\end{array}$ \\
\hline \multirow[t]{7}{*}{$\overline{\text { Bubanj }}$} & 8 & MAMS 31462 & $82 \mathrm{~A}$ (under the floor) & Ovis/Capra - radius & $4586 \pm 22$ & -16 & LE \\
\hline & & MAMS 31466 & Structure $49 / 93$ & $\begin{array}{l}\text { Mammal - part of long } \\
\text { bone }\end{array}$ & $4494 \pm 24$ & -23.4 & EBA 1 \\
\hline & & MAMS 31465 & Structure 42 (hearth) & $\begin{array}{l}\text { Part of diaphysis of long } \\
\text { bone }\end{array}$ & $4481 \pm 23$ & -21.5 & EBA 1 \\
\hline & & MAMS 31458 & Structure 83 & Bos taurus - humerus & $4400 \pm 25$ & -27.2 & EBA 1 \\
\hline & & MAMS 31459 & 15/2 (level with shells) & Bos taurus - metatarsal & $4398 \pm 23$ & -19.6 & EBA 1 \\
\hline & & MAMS 31464 & 40 (group of river stones) & Sus - metapodial & $4289 \pm 23$ & -18.8 & EBA 1 \\
\hline & & MAMS 31461 & Structure 91 & Bos taurus - pelvis & $3718 \pm 22$ & -16.4 & EBA 3 \\
\hline Dučalovići, Ruja & 4 & MAMS 31473 & Mound 12 & Human bone & $3892 \pm 16$ & -19.8 & EBA 2-3 \\
\hline \multirow{2}{*}{ Glogovac, Polje } & 9 & MAMS 31479 & (Triple) Grave 1, skeleton 2 & Human & $4188 \pm 16$ & -16.2 & EBA 1 \\
\hline & & MAMS 31478 & (Triple) Grave 1, skeleton 1 & Human & $4164 \pm 16$ & -19.4 & EBA 1 \\
\hline $\begin{array}{l}\text { Jančići, Veliko } \\
\text { polje }\end{array}$ & 2 & MAMS 31474 & $\begin{array}{l}\text { Mound, central grave, } \\
\text { inhumation }\end{array}$ & Human & $4119 \pm 15$ & -17.8 & EBA 2 \\
\hline $\begin{array}{l}\text { Krstac, Ivkovo } \\
\text { Brdo }\end{array}$ & 5 & RICH 24515 & Mound 1, stone cist & Cremated human bone & $3958 \pm 31$ & -22 & EBA 2-3 \\
\hline $\begin{array}{l}\text { Lučani, Suva } \\
\text { Česma }\end{array}$ & 17 & RICH 24503 & $\begin{array}{l}\text { Mound, central grave, } \\
\text { incineration }\end{array}$ & Cremated human bone & $3831 \pm 30$ & -21.9 & EBA 2-3 \\
\hline \multirow[t]{2}{*}{ Mokranjske Stene } & 1 & MAMS 31469 & Trench 2 , spit 12 & Bos taurus - tibia & $4444 \pm 22$ & -17 & EBA 1 \\
\hline & & MAMS 31468 & Trench 2, spit 7 & Ovis/Capra - femur left & $4441 \pm 24$ & -21.3 & EBA 1 \\
\hline Pelince & 11 & MAMS 31472 & Ritual area, quadrant Б28 & $\begin{array}{l}\text { Large mammal - long } \\
\text { bone }\end{array}$ & $3843 \pm 22$ & -17.7 & EBA 3 \\
\hline Prijevor, Ade & 3 & RICH 24502 & $\begin{array}{l}\text { Mound, central grave, } \\
\text { incineration }\end{array}$ & Cremated human bone & $3638 \pm 30$ & -23.7 & EBA 3 \\
\hline
\end{tabular}


Table 1 (Continued)

\begin{tabular}{|c|c|c|c|c|c|c|c|}
\hline Site & $\begin{array}{l}\text { N. on } \\
\text { map }\end{array}$ & Lab code & Context & Sample & $\mathrm{BP}$ & $\begin{array}{c}\delta^{13} \mathrm{C} \\
\% 0\end{array}$ & $\begin{array}{l}\text { Rel. } \\
\text { Chron }\end{array}$ \\
\hline \multirow{6}{*}{$\begin{array}{l}\text { Ranutovac, } \\
\text { Meanište }\end{array}$} & 10 & RICH 24516 & Grave 3 & Cremated human bone & $3701 \pm 31$ & -17.4 & EBA 3 \\
\hline & & RICH 24542 & Grave 21 & Cremated human bone & $3644 \pm 31$ & -17.3 & EBA 3 \\
\hline & & RICH 24543 & Grave 17 & Cremated human bone & $3594 \pm 31$ & -20.2 & EBA 3 \\
\hline & & RICH 24513 & Grave 9 & Cremated human bone & $3584 \pm 32$ & -22.1 & EBA 3 \\
\hline & & RICH 24544 & Grave 1 & Cremated human bone & $3548 \pm 33$ & -25.8 & EBA 3 \\
\hline & & RICH 24514 & Grave 7 & Cremated human bone & $3543 \pm 33$ & -29 & EBA 3 \\
\hline \multirow[t]{2}{*}{$\begin{array}{l}\text { Velika Humska } \\
\text { Čuka }\end{array}$} & 7 & MAMS 31475 & Trench I/16s, structure 6A & $\begin{array}{l}\text { Large mammal - long } \\
\text { bone }\end{array}$ & $4103 \pm 16$ & -24.1 & EBA 2 \\
\hline & & MAMS 31477 & Cultural layer BH III & $\begin{array}{l}\text { Bos/Cervus metapodial } \\
\text { bone }\end{array}$ & $3885 \pm 16$ & -17.5 & EBA 3 \\
\hline
\end{tabular}


The sample was not used in the model presented hereafter, but it is published here for the completeness of the information. The first sample (MAMS-31466) was taken from the remains of the Late Eneolithic dwelling structure 49/93, which according to pottery and stratigraphy (cultural layer IV) belongs to the Cotgofeni-Kostolac group (Figure 2/1-3). This group is generally dated to the end of 4th and beginning of the 3rd millennium cal BC (e.g. Bulatović and Vander Linden 2017) and is distributed across the mountainous parts of the Iron Gates hinterland. It is characterized by the occurrence of both Kostolac- and Cotgofeni-type ceramics, and by a variety of settlement types (hillforts, plateau and lowland settlements, caves) suggesting an economy based on transhumant herding and landscape control (Kapuran and Bulatović 2012: 77; Kapuran et al. 2018: 84). Cultural layer IV also yielded sample MAMS-31465, taken from structure 42, a fireplace. Associated pottery is characteristic of the same group (Figure 2/4-5). Sample MAMS-31459 was taken from the remains of dwelling structure 15, belonging to layer IV also belonging to the CotofeniKostolac group. Cultural layer V provided both sample MAMS-31458, taken from the rectangular dwelling structure 83, and sample MAMS-31464, from structure 40 (a concentration of river stones and potsherds). Pottery from both structures has CotgofeniKostolacelements and also stylistic and typological traits similar to the Vučedol group (Figure 2/9-13). This is not unusual considering the Vučedol influence in this period in the Morava Valley (Bulatović and Milanović 2020: 129-139). The last sample from Bubanj, MAMS-31461, was taken from structure 91, a pit which was dug from the lower level of layer $\mathrm{V}$ deep into layer IV. Associated pottery belongs to the Bubanj-Hum III group (Figure 3/6-7) with some elements of the Bubanj-Hum II group (Figure 3/8).

The site of Mokranjske Stene lies about $8 \mathrm{~km}$ south of Negotin in eastern Serbia, not far from the Timok River and the Serbian-Bulgarian border. It encompasses both the hilltop and the foot of the hill along the rocky walls. Excavations undertaken between 2011 and 2013 revealed a small rock-shelter with stratified prehistoric deposits (Bulatović 2015; Bulatović et al. 2018). The two samples presented here were taken from spits 7 (MAMS-31468) and 12 (MAMS-31469), excavated in trench 2. Spit 7 was formed by a light brown soil and yielded pottery characteristic of the Cotofeni-Kostolac group, while spit 12 corresponded to a yellow soil, containing mixed pottery of Bubanj-Hum I and Coţofeni-Kostolac groups (Figure 2/6-8). Bubanj-Hum I belongs to the Bubanj-Salcuţa-Krivodol cultural complex and dates to the early Eneolithic (Bulatović and Vander Linden 2017).

The site of Velika Humska Čuka is, with Bubanj, the eponymous site of the Bubanj-Hum culture (Garašanin M. 1958a). It is located on the top of a hill at the edge of the Niš plain, about $8 \mathrm{~km}$ northeast from Niš in southeastern Serbia. In 2014, remains of settlements dated to Early and Late Copper Age, Bronze Age, Iron Age and Roman period were uncovered (Bulatović and Milanović 2015). The first sample (MAMS-31475) was taken from a dwelling structure (structure 6A) in trench $\mathrm{I} / 16 \mathrm{~S}$, with numerous potsherds belonging to Bubanj-Hum II group (Figure 2/16-18). The second sample (MAMS-31477) was taken from a pottery scatter in excavation spit 6 attributed to the Bubanj-Hum III group (Figure 3/1-3). The scattered pottery was quite homogeneous from a stylistic and typological point of view. On the other hand, the older layer beneath the pottery scatter belonged to the Cotgofeni-Kostolac group, which is dated to between 32nd and 29th century cal BC (Bulatović and Vander Linden 2017; this study). For this reason, the possibility that this sample belongs to the older layer and thus to a preceding phase can be excluded. 


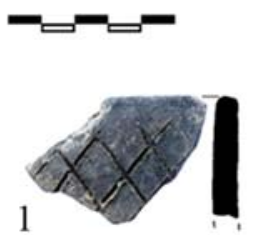

2

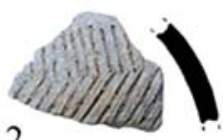

3

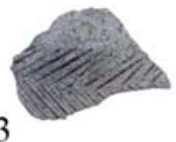

4

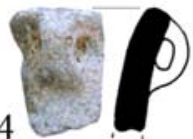

5

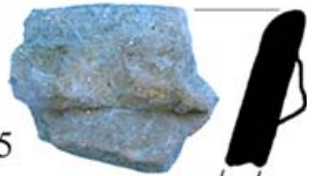

6

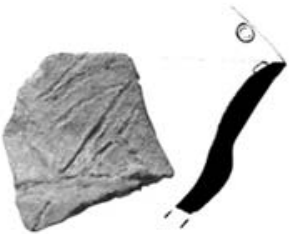

7
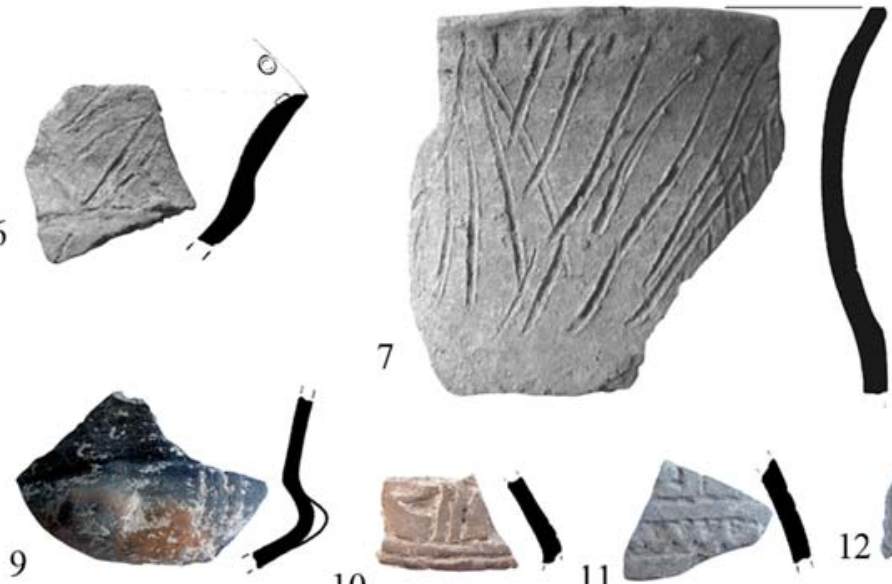

10

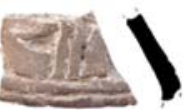

11

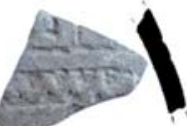

12
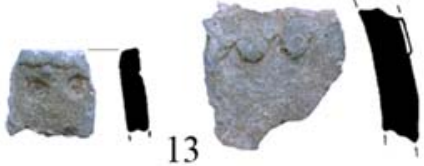

16

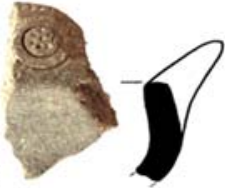

15
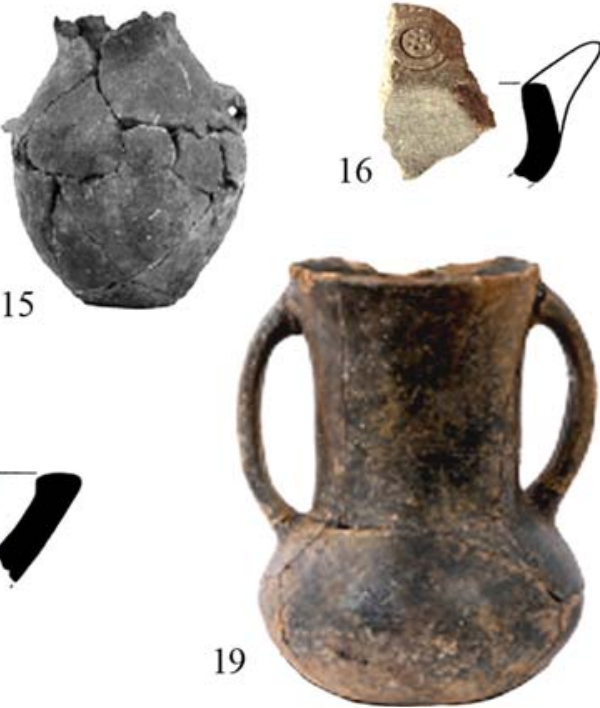

Figure 2 1-3. Bubanj, str. 49/93; 4-5. Bubanj, str. 42; 6-8. Mokranjske Stene; 9-11. Bubanj, structure 83; $12-13$. Bubanj, structure 40; 14-15. Jancici, Veliko Polje, grave 2; 16-18. Velika Humska Čuka, structure 6A; 19. Dučalovići, Ruja, mound 12, grave 1.

\section{Ritual Space}

The site Pelince Dve Mogili ("Two Mounds") is situated on a hill overlooking the Pčinja River, in the northern part of North Macedonia, near the border with Serbia. The site was excavated in the late 1980s and early 1990s (Trajkovska 1995; Trajkovska 2003; Bulatović and Stankovski 

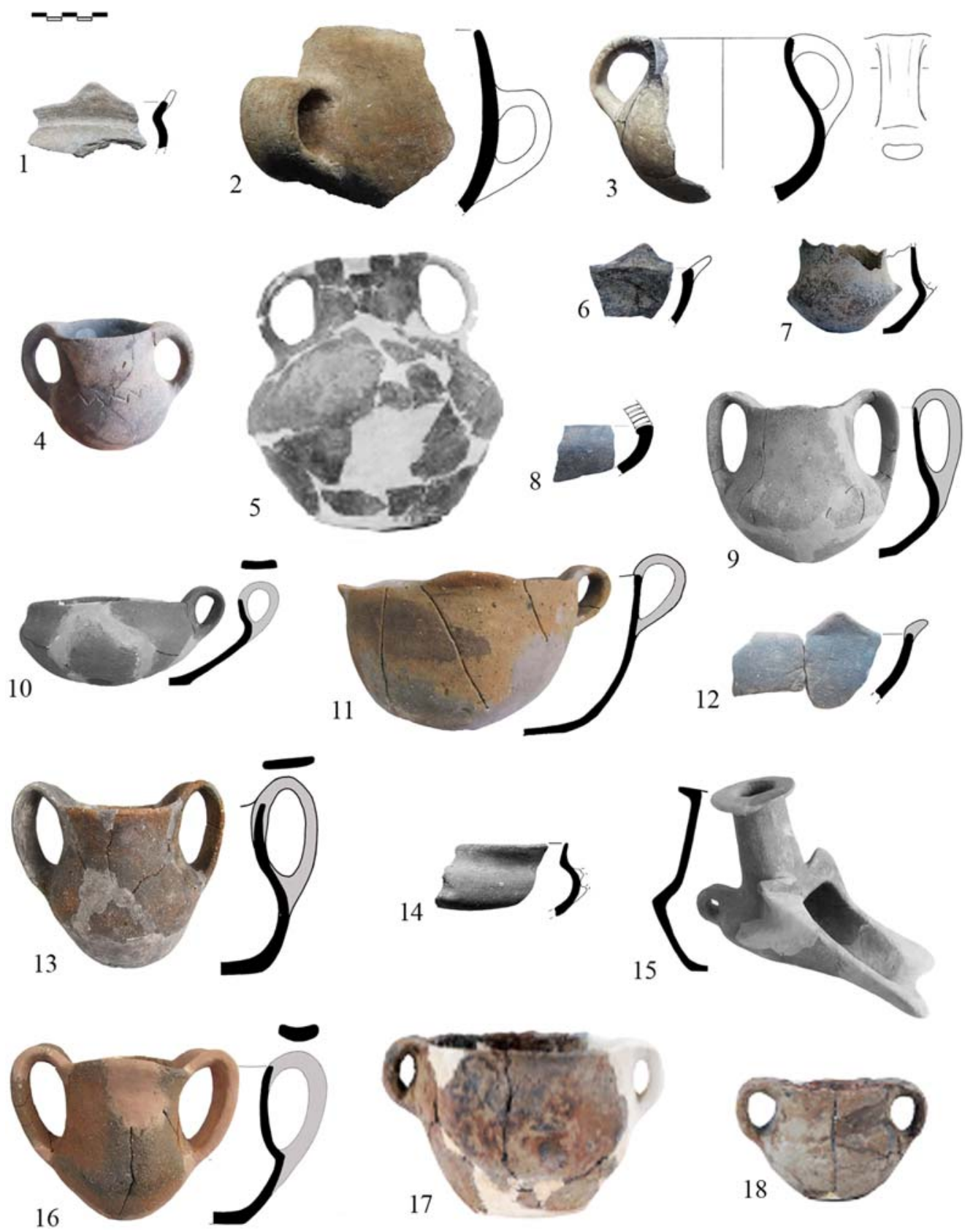

Figure 3 1-3. Velika Humska Čuka; 4. Pelince, Dve Mogili, pit Б 28; 5. Lučani, Suva Česma, mound 7, central grave; 6-8. Bubanj, structure 91; 9-10. Ranutovac, grave 3; 11-13. Ranutovac, grave 17; 14. Ranutovac, grave 1; 15. Ranutovac, grave 7; 16. Ranutovac, grave 21; 17-18. Prijevor, Ade, mound, central group of vessels.

2012). Two areas, interpreted as ritual spaces, were excavated, containing a few dozens shallow circular pits and three pyres covered by earth. The single sample dated here (MAMS-31472) was taken from a pit in quadrant 528, about $10 \mathrm{~m}$ south of the central pyre (Bulatović and Stankovski 2012: Figure 11). Pottery from the pit (Figure 3/4) belongs 
to the Bubanj-Hum III-Pelince-Pernik complex, which covers a variety of sites from western Bulgaria, southern Pomoravlje, eastern Serbia and northeastern part of North Macedonia (Bulatović 2014: 68).

\section{Cemeteries_-Inhumations}

Two samples were obtained from Polje, in the municipality of Glogovac, southeastern Serbia. The site lies on the left bank of the Crvena Reka and was investigated in 2011-2012 during rescue excavations prior to the construction of a highway (Lazić and Ljuština 2017). Besides the remains of settlements dating to the Copper, Bronze and Iron Ages, one triple grave was also uncovered, from which we obtained two dates (MAMS-31478, MAMS31479). All skeletons were buried in a crouched position, lying one behind the other. Although the burials did not contain any grave goods, pottery belonging to the Late Coţofeni-Kostolac group, with some Vučedol elements, was found nearby. The Vučedol group initially develops in eastern Slavonia and Srem following the Kostolac group, before undertaking a phase of spatial expansion with both settlements and cemeteries observed across the Carpathian Basin, the western Balkans, and beyond Eastern Europe and the Adriatic.

The site of Veliko Polje is located on the northern slope of the Kablar Mountain in the Jančići village near Čačak, western Serbia. Several funerary mounds are distributed over an elongated ridge, and one of them was excavated in 1979 (Dmitrović 2016: 58-60). The mound, $13 \mathrm{~m}$ in diameter, consists of an inner sod-and-earth mound (diam.: $6 \mathrm{~m}$ ), with an outer layer of stones. The central mound contained a stone cist, with a skeleton in crouched position (grave 2) from which sample MAMS-31474 was taken. A small vessel was found in association with the skeleton (Figure 2/15), and another one close to the cist (Figure 2/14). The second presents characteristic Vučedol decoration.

The site of Ruja lies near the village of Dučalovići, western Serbia. This cemetery includes 23 mounds. Five of them, in a better state of preservation, were excavated between 1978 and 1979 (Dmitrović 2002). Mound 12 measures about $10 \mathrm{~m}$ in diameter and is $1.2 \mathrm{~m}$ high and is made of earth. It contained two graves, including a central stone cist (grave 1), with a skeleton in crouched position, from which sample MAMS-31473 was taken. This grave was associated with a two-handled beaker (Dmitrović 2016: 51-57; Figure 2/19) belonging from a typological point of view to the Belotić-Bela Crkva group. Centred upon western Serbia, this Early Bronze Age group is so far only defined through material culture found in cemeteries of clustered barrows. As most of the Belotić-Bela Crkva pottery is undecorated, existing typologies are based on morphological criteria only and point to links with other contemporary groups in the region, especially the Vinkovci-Somogyvár group.

\section{Cemeteries-Cremations}

Ivkovo Brdo is situated on the Krstac Mountain, western Serbia. The site consists of several mounds, five of which were excavated (Nikitović 2003). The sample reported here ( $\mathrm{RICH}-24515)$ was taken from mound 1 , which measures 10 to $15 \mathrm{~m}$ in diameter and is composed by earth and stone slabs. A central stone cist contained the remains of a cremated individual together with one stone triangular arrowhead (Dmitrović 2016: 95-103). Several potsherds were recovered within the body of the mound, but none of them presenting any diagnostic feature. Nevertheless, this context was selected because of its architectural characteristics and the use of cremation. 
The site of Suva Česma in Lučani is located on the western slope of Ruja Mountain, western Serbia. Eight mounds were recorded during a survey in the early 1970s, but only mound 7 survived and was recently excavated (Dmitrović 2016: 110-115). Its earthen cover was irregular in shape, and measured ca. $12-15 \mathrm{~m}$ in diameter. In the northwestern part of the mound, a circular construction made of stones contained cremated human bones (RICH-24503), a handstone, and some potsherds belonging to four vessels (Figure 3/5) attributed to the Belotić-Bela Crkva group.

The site of Meanište in Ranutovac was excavated in 2012 prior to the construction of a highway. It is located about $5 \mathrm{~km}$ northeast from Vranje, in southeastern Serbia (Bulatović, Bizjak and Vitezović 2016). The site lies on a slight slope about $600 \mathrm{~m}$ from the modern riverbed of the Južna Morava. Together with an Early Iron Age settlement, an Early Bronze Age cemetery was uncovered. The cemetery comprised 21 graves distributed over three separated areas. The graves consisted of circular shallow pits around $0,5 \mathrm{~m}$ in diameter, surrounded and covered by stones. Remains of cremated human bones were discovered lying at the bottom of the pits, associated with various vessels, mostly cups. Six samples from different graves were sent for analysis (RICH-24516, RICH-24542, RICH24543, RICH-24513, RICH-24544, RICH-24514). Pottery grave goods (Figure 3/9-16) belong to the Armenochori group, which is distributed in northwestern Greece, southeastern Albania and southwestern North Macedonia. At present Ranutovac-Meanište marks the northernmost extension of this group.

The cemetery of Ade in Prijevor near Čačak, in western Serbia, is located on the river terrace close to the confluence of the Kamenica and Zapadna Morava rivers (Stojić and Nikitović 1996). The mound consisted of an earthen cover surrounded by a circular ring of river pebbles, and comprised four distinct features, indicating its long-lasting use as a burial place: the primary grave 1 (which dates to the Early Bronze Age), grave 2 (which dates to the Late Bronze Age), a group of vessels placed in the centre of the mound, and a pyre. Grave 1, for which we obtained a radiocarbon determination, is located in the western part of the mound, and consists of a shallow pit about $1 \mathrm{~m}$ in diameter filled with cremated human bones (RICH-24502), charcoal and two river stones (Dmitrović 2016: 136-139). Grave 1 did not include any grave good. However, on the basis of typological characteristics, the central group of vessels can be attributed to Bubanj-Hum III or succeeding Bubanj-Hum IV-Ljuljaci groups (Figure 3/17-18).

\section{METHODS}

Radiocarbon samples were processed by two distinct laboratories. Bone samples were submitted for counting to MAMS, the AMS facility at the Curt-Engelhorn-Centre for Archaeometry, Mannheim, and were treated following the standard protocol in operation there (Kromer et al. 2013). Cremated human remains were sent to the KIK-IRPA AMS laboratory, Royal Institute for Cultural Heritage, Brussels (Boudin et al. 2015). They were pretreated following Van Strydonck et al. (2009). Hereafter $\mathrm{CO}_{2}$ of the cremated bone was released by adding phosphoric acid and graphitization, following Van Strydonck and van der Borg (1990-1991). As dates on cremated bone actually correspond to the atmospheric ${ }^{14} \mathrm{C}$ during the cremation process, a possible offset between this date and the death of the sampled individual cannot be ruled out because of, for instance, use of very old wood or fossil fuel in the pyre. However, for prehistoric Europe, such offset is generally considered to be minimal and comparable to the decadal inbuilt age of the adult human skeletal 
(Snoeck et al. 2014). The $\delta^{13} \mathrm{C}$ value (see Table 1) was obtained from the isotope determination in the AMS system. This value may be influenced by isotope fractionation and is only used for fractionation correction. Hence, this value is not comparable to the one obtained in a stable isotope IRMS and should not be used for further data interpretation.

All dates were calibrated using OxCal 4.3 (Bronk Ramsey 2009). In the case of Bubanj, a Bayesian model was built (Figure 5) by combining the radiocarbon dates with the stratigraphic information, the latter providing the necessary prior beliefs (e.g. Bayliss et al. 2007). Given the complexity and relative uncertainties of the stratigraphy of the site, our model distinguishes two successive phases corresponding, on the one hand, to layer IV and V/lower horizon (which yielded pottery attributed to the Late Eneolithic Cotofeni-Kostolac group), and, on the other hand, layer V/upper horizon (with pottery belonging to the EBA Bubanj-Hum III group). When multiple dates were available for the same site (e.g. Mokranjske Stene, Ranutovac), a simple Bayesian model was built as a single bounded sequence, thus providing quantitative estimates for the start and end of the modeled phases. The same approach was adopted for collating and analysing dates belonging to the same cultural group. Despite this, it must be noted that, in several instances, the resulting models remain relatively imprecise, either due to limited information, or to the shape of the calibration curve of the $3 \mathrm{rd}$ millennium cal $\mathrm{BC}$, characterized by a succession of plateaus and peaks.

\section{RESULTS AND DISCUSSION}

\section{Early Bronze Age 1}

Of the 25 dates presented in this paper, ten belong to the Late Eneolithic, according to Serbian chronology, or Early Bronze Age 1 (hereafter EBA 1) following the chronology used in Greece and Bulgaria. Six originate from Bubanj, two from Mokranjske stene, and two from Polje in Glogovac (Table 1). According to stylistic and typological characteristics of ceramics and other finds, the EBA 1 levels of these sites were attributed to the Cotgofeni-Kostolac group as defined by Jovanović (1976), followed by Tasić (1979), Nikolić (1997) and Kapuran and Bulatović (2012). A total of 29 dates from Serbia and Romania are included in the EBA 1 model, comprising the following sites: Bubanj (Bulatović and Vander Linden 2017), Mokrajnske Stene, Jančići, Glogovac, Vučedol (Benkö et al. 1989), Pivnica (Durman and Obelić 1989, Forenbaher 1993), Gomolava (Durman and Obelić 1989, Forenbaher 1993), Belovode (Borić 2009), Ostrovul Corbului (Breunig 1987), Băile Herculane (Breunig 1987), Poiana Ampoiului (Ciugudean 1996). The beginning of this cultural group falls between 3207 and $3105 \mathrm{cal} B C(68.2 \%$ probability), or 3344 and 3097 cal BC (95.4\% probability), while its end dates to between 2864 and 2806 cal BC (68.2\% probability), or 2878-2739 cal $B C(95.4 \%$ probability). The duration of this group is estimated at 255-402 years (68.2\% probability), or 234-587 years (95.4\% probability) (Figure 4).

The Cotofeni-Kostolac group at Bubanj is concurrent with the presence of Kostolac and Coţofeni groups across modern-day Serbia. At Bubanj the model for the Cotgofeni-Kostolac group was based on seven dates, of which two (SUERC-69296 and SUERC-69297) have been previously published (Bulatović and Vander Linden 2017). The Cotgofeni-Kostolac group starts between 3273 and $3106 \mathrm{cal} B C(68.2 \%$ probability), or 3344 and $3100 \mathrm{cal}$ $B C$ (95.4\% probability) and ends between 2856 and 2749 cal BC (68.2\% probability), or 


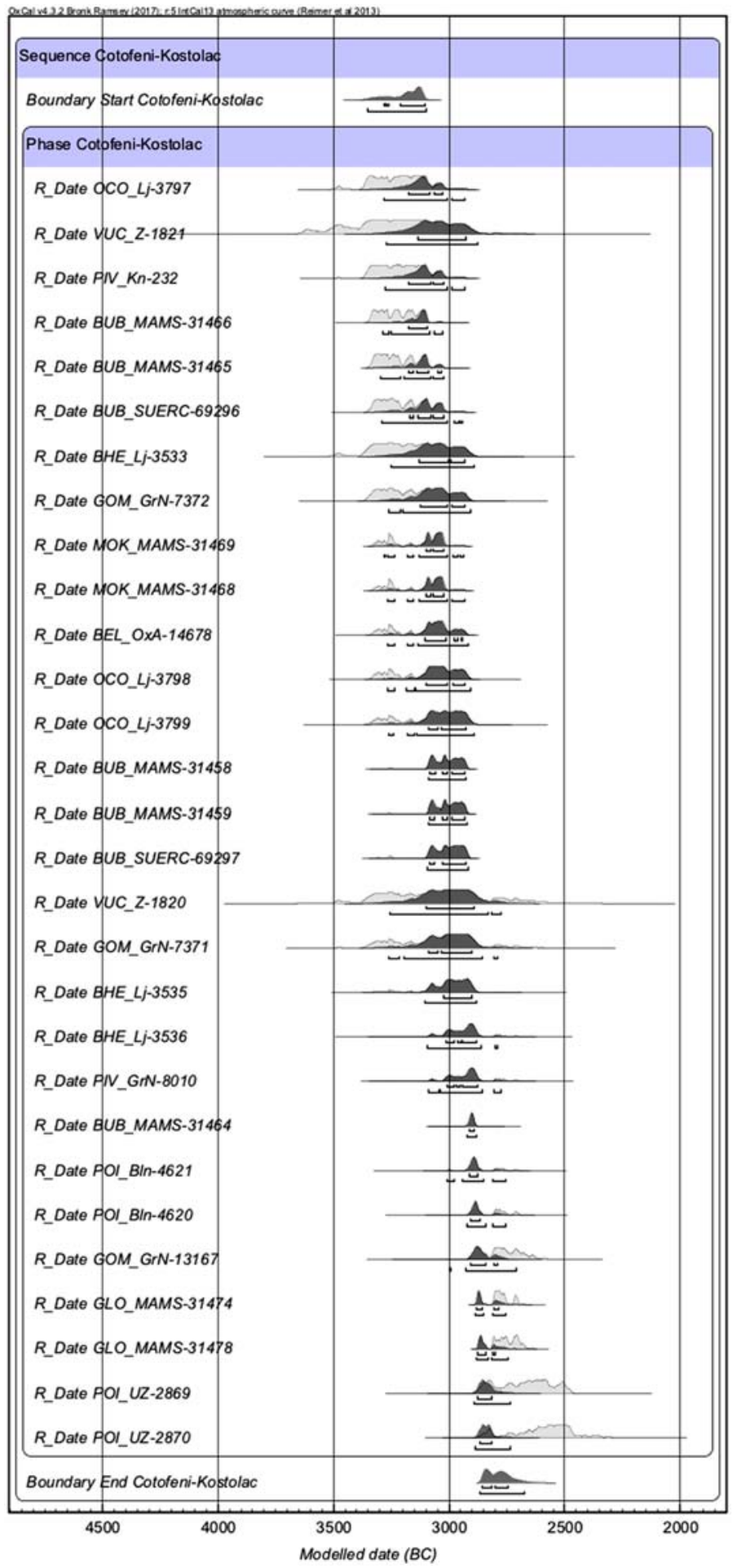

Figure 4 Bayesian modeling of ${ }^{14} \mathrm{C}$ dates for the Coţofeni-Kostolac group, EBA 1 $(\mathrm{BEL}=$ Belovode, $\mathrm{BHE}=$ Baile Herculane, $\mathrm{BUB}=$ Bubanj, $\mathrm{GLO}=$ Glogovac, $\mathrm{GOM}=$ Gomolava, $\mathrm{MOK}=$ Mokranjske stene, $\mathrm{PIV}=$ Pivnica, $\mathrm{OCO}=$ Ostrovul Corbului, POI = Poiana Ampoiului, VUC $=$ Vučedol.) 


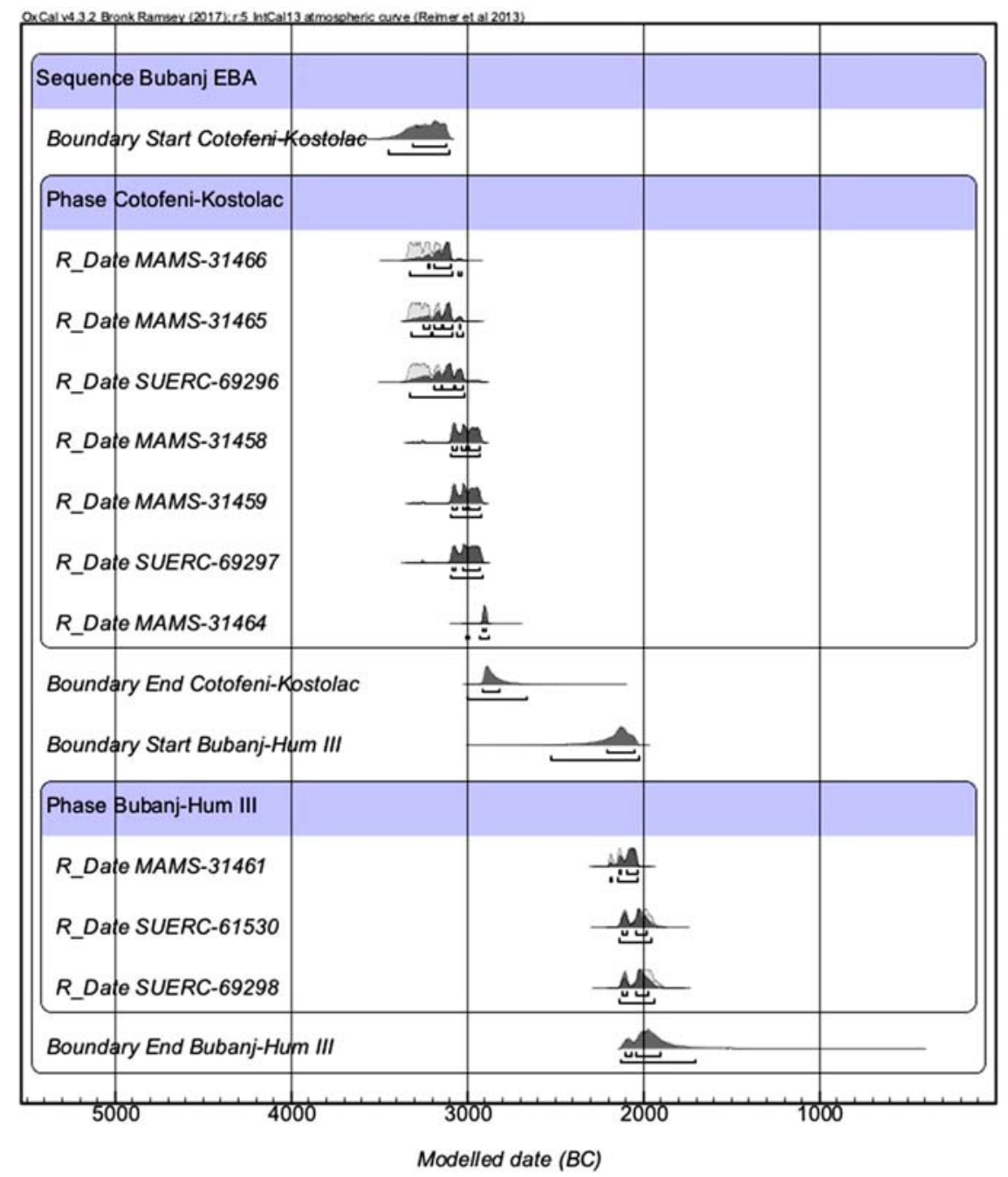

Figure 5 Bayesian modeling of ${ }^{14} \mathrm{C}$ dates for the Coţofeni-Kostolac (EBA 1) and Bubanj-Hum III (EBA 3) groups from Bubanj.

2866 and 2684 cal BC $(95.4 \%$ probability). It thus spans a duration of $265-461$ years $(68.2 \%$ probability) or $248-628$ years $(95.4 \%$ probability) (Figure 5, top). In respect to the previously published results (Bulatović and Vander Linden 2017), the chronological definition of the Coţofeni-Kostolac group at Bubanj improved thanks to a better data set and thus more reliable Bayesian model. The dates in this paper further improve the chronological framework of the EBA 1 in the central Balkans and challenge the well-established assumption that the Cotgofeni-Kostolac group would be younger than both Kostolac and Cotgofeni groups. The younger dates from Cotgofeni-Kostolac layers at Bubanj and Glogovac, and the date for the following EBA 2 phase at Velika Humska Čuka combined with stylistic and typological analysis of ceramics suggest that there is no significant chronological hiatus between the EBA 1 Cotofeni-Kostolac and the following EBA 2 Bubanj-Hum II groups. 


\section{Early Bronze Age 2}

Two samples date to Early Bronze Age 2 (hereafter EBA 2; or Late Eneolithic using the existing Serbian system), the first one originates from Jančići in western Serbia (MAMS-31474), and it comes from an inhumation grave under a tumulus, in which an early-classical Vučedol vessel was discovered (Dimitrijević 1979: Figure 4/19-22). The grave in Jančići is dated to a period between 2849 and 2627 cal BC with $68.2 \%$ probability, which approximately corresponds to the classical horizon of the Vučedol group (Durman and Obelić 1989: Table 1). Vessels similar for shape but with slightly different decoration, were recorded near Loznica (Garašanin M. and Garašanin D. 1962: Figure 12), in a mound attributed to the Belotić-Bela Crkva group. The second sample originates from a possibly residential structure in Velika Humska Čuka (MAMS-31475), in which exclusively Bubanj-Hum II pottery is recorded (Figure 2/16-18). This group has been defined by Garašanin M. (1958b) on the basis of stylistic and typological ceramic features of Bubanj and other sites, and stratigraphy at Bubanj. Its origins and its relationship with similar cultural phenomena in the surrounding areas (e.g. horizon IIB in Dubene, and horizons 85 of Junacite in central Bulgaria, Bagačina in NW Bulgaria: Nikolova 1999; Alexandrov 2007) are still unclear. In terms of ceramic style and typology, Bubanj Hum II holds some elements of the previous Coţofeni-Kostolac group, however typical Vučedol decorative traits are also present. Besides pottery, contacts between these groups are also suggested by the contemporaneity between the absolute dates for the Vučedol group, and the sole date for the Bubanj-Hum II group, published here. The Vučedol ceramic horizon is distributed over a large part of the Balkans comprising Pannonia and the entire East Adriatic coast, and has been dated to the first half of the 3rd millennium BC, probably from around 2900 to 2600 cal BC (Forenbaher 1993: 247; Velušček and Čufar 2014: 42-43; Forenbaher 2018a: 133). The dating from Velika Humska Čuka (MAMS-31475; 2835-2587 cal BC, $68.2 \%$ probability, 2851-2579 cal BC, 95.4 probability) represents the oldest from a Bubanj-Hum II context, since at Dubene a somewhat younger date is recorded (2580-2470 cal BC with $68.2 \%$ probability). Data for the horizons $8-5$ at Junacite, where pottery with identical decoration as at Velika Humska Čuka is recorded (Nikolova 1999: 203, 227, Table 9.2, Table 10.2) indicate an even younger dating (2402-2210 cal BC with $68.2 \%$ probability). At present EBA 2 remains the most poorly defined horizon of the 3rd millennium cal BC in the area under analysis, however it is now clear that it is contemporaneous with the EBA 2 Bulgarian Dubene group (Nikolova 1999; Nikolova and Görsdorf 2002).

\section{Early Bronze Age 2-3}

Most of the dates presented in this study (13 in total) belong to the EBA 2-3 and EBA 3 or the final stage of the Late Eneolithic and beginnings of the Early Bronze Age according to Serbian chronology. The oldest dates come from two samples taken from cist graves under tumulus located in different areas of western Serbia. While the deceased from Krstac was cremated (RICH-24515), the burial from Dučalovići was an inhumation (MAMS-31473) (Dmitrović 2016: 50-57, 94-103). Interestingly, the two dates are quite close. Based on the characteristics of pottery from Dučalovići (Figure 2/19), the tumulus can be assigned to the Belotić-Bela Crkva group, which was defined by M. Garašanin who also underlined the coexistence of both rituals within the group (Garašanin M. 1973: 253-266). The cremation burial at the tumulus in Lučani ( $\mathrm{RICH} 24503)$ was assigned to the Belotić-Bela Crkva group on the basis of typological characteristics of the grave goods (Figure 3/5). Although 


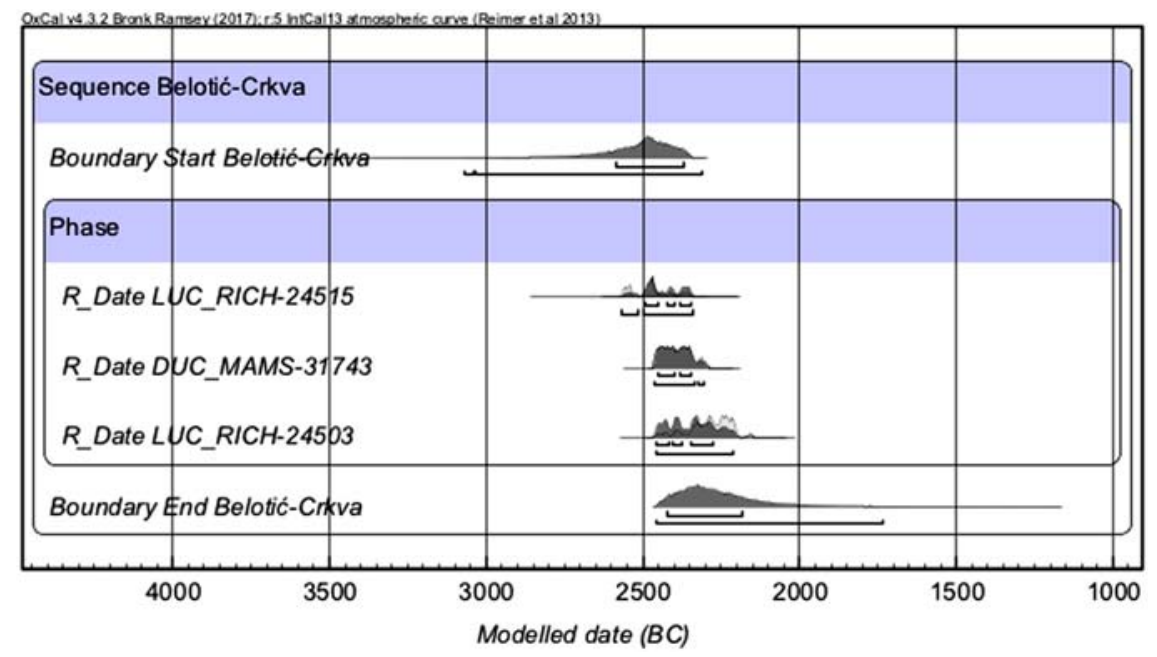

Figure 6 Bayesian modeling of ${ }^{14} \mathrm{C}$ dates for the Belotić-Bela Crkva group, EBA 2-3 $(\mathrm{DUC}=$ Dučalovići, LUC $=$ Lučani).

no diagnostic ceramics were recorded in the burial of Krstac, given its chronology, which is comparable to Dučalovići, and the fact that both cremation and inhumation are attested within the Belotić-Bela Crkva group, it can be assumed that the tumulus from Krstac belongs to the same group.

According to the Bayesian model (Figure 6), the start of Belotić-Bela Crkva falls between 3068 and 2311 cal BC (95.4\% probability), or 2586-2366 cal BC (68.2\% probability). The end dates to between 2461 and $1718 \mathrm{cal} \mathrm{BC}(95.4 \%$ probability), or $2431-2198 \mathrm{cal}$ $B C(68.2 \%$ probability). Based on these dates, the group would last $0-1197$ years (95.4\% probability), or $0-368$ years $(68.2 \%$ probability). Large temporal brackets for all measures at $95.4 \%$ probability are related to the low number of dates included in the model, and the absence of true boundaries.

The chronology of Belotić-Bela Crkva and its comparison to other groups has been always rather problematic (Maran 1998: 322). Even if uncertainty remains, it is possible to propose that Belotić-Bela Crkva is contemporaneous with the neighbouring Vinkovci-Somogyvár group (Kalafatić 2006: Table A; Kulcsár 2013: Table 1), somewhat younger than MakóKosihy Čaka (Kulcsár 2009: 15), and older than the Moriš group (Nikolova 1999: 405). The existence of an EBA 2-3 chronological horizon embodied by the Belotić-Bela Crkva group, is supported by the Loznica findings (Garašanin M and Garašanin D 1962: Figure 12), in which Belotić-Bela Crkva ceramics were found together with ceramics with elements of classical Vučedol group. Belotić-Bela Crkva is also connected to the Adriatic Cetina group. The presence of Cetina material culture in the interior of the Balkans is well-attested; for instance, pottery finds in several sites in Bosnia and Herzegovina and western Serbia (Govedarica 2006; see below), and by numerous vessels with distinctive traits from both Cetina and Belotić-Bela Crkva (e.g. Vrtanjak; Govedarica 2006: 36).

The Cetina group is identified by its characteristic decorated pottery and burials under tumuli, which spread in the central Balkans (Govedarica 2006; Forenbaher 2018a) and over Dalmatia 
down to Peloponnese and further across the Central Mediterranean in the second half of the 3rd millennium cal BC. Given the paucity of stratified and closed Cetina contexts and of ${ }^{14} \mathrm{C}$ dating, to propose a reliable chronology for this widespread and long-lasting phenomenon represents a challenging enterprise (see recently Forenbaher 2018a: 135-140). It is clear that that the Ljubljana-Cetina phenomenon comprises several phases covering much of the 3rd millennium cal BC. The earliest one (Ljubljana-Adriatic) seems to belong to the second quarter of the third millennium BC, while the last two (here referred to as Cetina 1 and Cetina 2) are likely to encompass both the second half of the 3rd and the first century of the 2nd millennium cal BC (Gori 2020). On the basis of absolute dating combined with ceramic typology from different sites in the Mediterranean, Jung and Weninger (2015) suggest a terminus post quem for their classic Cetina (corresponding to Cetina 2) around 2250 cal BC. It can be thus suggested that Belotić-Bela Crkva is contemporaneous with the phase Cetina 1, while Cetina 2 would be contemporaneous with Bubanj-Hum III and the second horizon of Armenochori (see here below). The last is also suggested by the presence of few decorated potsherds with Cetina 2 features in Sovjan level 7 (Gori 2015a). However, it has to be noted that tankards recalling Belotić-Bela Crkva examples were recovered in both Sovjan levels 8 and 7 (Gori 2015a: 87-90). This is the first attempt of correlating absolute chronology of the central and western Balkans, however a larger number of radiocarbon dates from reliable contexts is required to improve this correlation and better understand cultural connections between these areas.

The correlation between central Balkan EBA 2-3 and northern Greece also presents some difficulties, as an intermediate period between EBA 2 and EBA 3 was only recognized in the southern Greek Mainland and in the Cyclades (Arvaniti and Maniatis 2018: 765-766, Table 2). On the contrary, the northern Greek sequence is divided in three phases, with corresponding Bayesian analysis (Arvaniti and Maniatis 2018: Fig. 6). This further confirms the need for a larger number of radiocarbon dates from reliable contexts and for cross-regional analysis.

\section{Early Bronze Age 3}

Four dates belong to the Bubanj-Hum III group, originally defined by M. Garašanin in the 1950s (Garašanin M. 1957: 205-207). The samples here analysed come from Velika Humska Čuka, Bubanj, Prijevor and Pelince. The Bayesian modeling of the dates available for the Bubanj-Hum III group, which comprise the aforementioned four dates and the further two from Bubanj already published (Bulatović and Vander Linden 2017) yielded the following results: Bubanj-Hum III group would start between 2723-2296 cal BC (95.4\% probability), or 2491-2296 cal BC (68.2\% probability), while its end would fall into 2085-1638 cal BC (95.4\% probability), or 2006-1859 cal BC (68.2\% probability). The duration of the Bubanj-Hum III group would be of $275-983$ years (95.4\% probability), or 365-633 years $(68.2 \%$ probability) (Figure 7$)$.

The earliest available date of this group comes from Velika Humska Čuka (MAMS-31477). This date is about two to three centuries older than the ones previously published for this group (Bulatović and Vander Linden 2017), and the other dates obtained with this study. Although we cannot totally exclude the risk of residuality for this particular sample, it is noticeable that this date, which originates from an archaeological context yielding stylistically and typologically homogeneous pottery, presents a large overlap with the second older date. The latter originates from the ritual area in Pelince (MAMS-31472), 


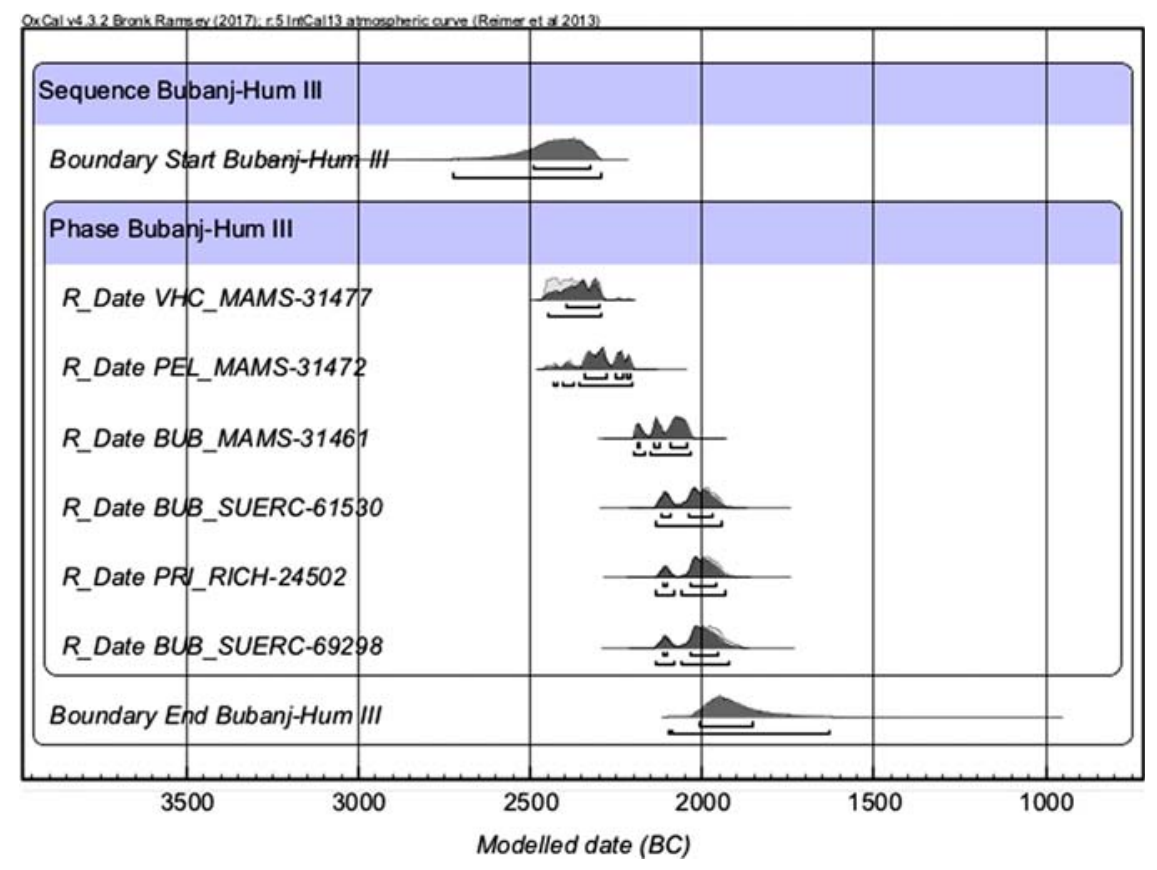

Figure 7 Bayesian modeling of ${ }^{14} \mathrm{C}$ dates for the Bubanj-Hum III group, EBA 3 (BUB = Bubanj, $\mathrm{PEL}=$ Pelince, $\mathrm{PRI}=$ Prijevor, $\mathrm{VHC}=$ Velika Humska Čuka).

which yielded numerous ceramic finds the stylistic and typological characteristics of which correspond to examples from southwestern Bulgaria and southeastern Serbia. By comparison, the other two dates (site of Bubanj, MAMS-31461; Prijevor, RICH-24502) are a little bit younger, pointing to the very end of the 3rd millennium cal $\mathrm{BC}$, or the beginning of the 2nd millennium cal BC. The name Bubanj-Hum III-Pernik-Pelince was suggested for this wider cultural phenomenon by one of the authors (Bulatović 2014: 68, Map 2).

Although these results should be taken with caution given the low number of available samples, when singling out the dates available for the Bubanj-Hum III group on the eponymous site of Bubanj, it seems that here this phase started with a delay of two to three centuries (Figure 5, bottom). The internal Bayesian model for Bubanj indicates that this phase started there between $2473-2030 \mathrm{cal} \mathrm{BC}(95.4 \%$ probability), or 2196-2048 cal BC (68.2\% probability). The end of Bubanj-Hum III group falls at Bubanj between 2129-1781 cal BC $(95.4 \%$ probability) and $2106-1916$ cal $B C(68.2 \%$ probability). Its duration is estimated at $0-604$ years ( $95.4 \%$ probability), or $0-237$ years ( $68.2 \%$ probability). The uncertainty towards the duration of the BH III group at $95.4 \%$ probability is related to the limited number of dates and the shape of the calibration curve for the 3rd millennium cal BC.

The last set of dates comes from Meanište in Ranutovac. According to typological characteristics of ceramics (Figure 3/9-14, 16; compare Bulatović, Bizjak and Vitezović 2016) and the presence of miniature oven models with long chimneys (Figure 3/15) (Bulatović 2013), referred to also as smoking pots (Gori 2015b: 45), this cemetery can be ascribed to the Armenochori group, of which Ranutovac represents its northernmost manifestation. Considering the model based exclusively on Ranutovac (Figure 10), the time 
in which the cemetery was in use is comprised to between $2237-1947$ cal BC $(95.4 \%$ probability), or $2119-1984 B C(68.2 \%)$ for its start, and to between $1971-1695$ cal BC (95.4\%), or $1933-1829$ cal $B C(68.2 \%$ for its end. In that case, the cemetery would have been in use for 0-470 years $(95.4 \%)$, or $74-294$ years $(68.2 \%)$.

It is noteworthy that there is no spatial coherence to these results, as for instance samples lying both at the beginning ( $\mathrm{RICH}-24516)$ or the end of the sequence (RICH-24514) come from the same sector. The same conclusion applies to all other samples. The cemetery of Ranutovac was partially damaged by agricultural works, so it remains unknown whether the graves were originally covered by one or several burial mounds. With the exception of Ranutovac, cemeteries that exclusively contained cremations have not been recorded in the central Balkans for the Early Bronze Age (Bulatović 2014: 66-67). A parallel can be established with Kriaritsi, a cemetery located in the Chalkidiki Peninsula (Asouhidou 2011). Both cemeteries are related by the exclusive use of cremation, funerary architecture and spatial organization of the graves. It must be noted however that pottery from Kriaritsi presents typological links with Thessaly and southern Greece (Wiencke 2000) rather than with Macedonia and central Balkans. The joint use of cremation and inhumation is attested at Xeropigado (Ziota 1998), Agios Mamas (Pappa 2010), and Nea Skioni (Tsigarida and Mantazi 2004) in northern Greece, and Steno on Lefkada (Dörpfeld 1927: 220-227). In these cases, cremation is always a minor form of body treatment. Structures from the last two sites present close similarities with the architecture of Kriaritsi (Forsén 2012: 55) and Ranutovac. Steno is a key site for Aegean-Balkan relationships both for the presence of diagnostic Balkan material culture (Kilian-Dirlmeier 2005) and because it is one of the few known examples of EH II-III tumuli in Greece (Müller Celka 2012: 415-416), an architectural type often assumed to originate from the Balkans. The combined use of cremation and inhumation is also attested in the entire Dalmatian region. Cetina cemeteries, dated to the second half of the 3rd millennium cal BC, comprise tumuli, often clustered, under which different types of burials are placed, including single or multiple inhumations (mostly but not exclusively in stone cists) as well as cremations possibly placed in urns (Marović 1991).

The site of Ranutovac is also important because of the typology of the ceramic grave goods, typical of the Armenochori group. In order to observe eventual spatial variation in the distribution patterns of Armenochori sites, two Bayesian models were produced: a comprehensive one for the group (Figure 8), and another one excluding Ranutovac (Figure 9). The global model (Figure 8) comprises 42 dates from Archontiko (Papaefthimiou Papanthimou and Pilali Papasteriou 1997), Mandalo (Maniatis and Kromer 1990), Ranutovac (present study), Sovjan (Lera and Touchais 2004; Gori 2015b), and Xeropigado Koiladhas (Maniatis and Ziota 2011). It shows that its start falls into 2467-2316 cal BC (95.4\% probability), or 2421-2351 cal BC (68.2\% probability), and its end by $1916-1784$ cal $B C$ (95.4\% probability), or $1901-1851$ cal BC (68.2\% probability), while the duration was estimated at 425-638 years (95.4\% probability), or 463-562 years (68.2\% probability). Without surprise given the amount of overlap between them both, the second model (i.e. excluding Ranutovac; Figure 9), provides strikingly similar results, with a start corresponding to $2473-2318$ cal BC (95.4\% probability), or 2422-2354 cal BC (68.2\% probability), and an end to $1932-1813$ cal BC $(95.4 \%$ probability) or $1911-1859$ cal $B C(68.2 \%$ probability), for a duration of $420-632$ years $(95.4 \%$ probability), or $460-557$ years $(68.2 \%$ probability). 


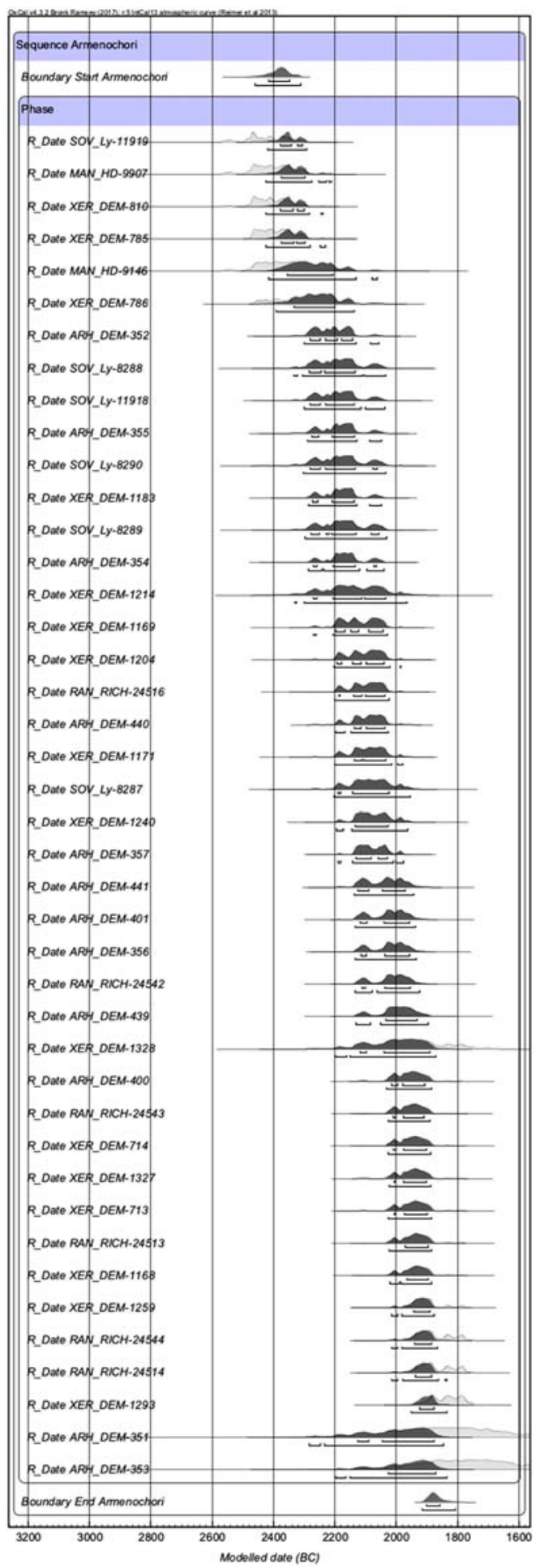

Figure 8 Bayesian modeling of ${ }^{14} \mathrm{C}$ dates for the Armenochori group, EBA 3, including Ranutovac $(\mathrm{ARH}=$ Archontiko, $\mathrm{MAN}=$ Mandalo, $\mathrm{RAN}=$ Ranutovac, $\mathrm{SOV}=$ Sovjan, $\mathrm{XER}=$ Xeropigado). 


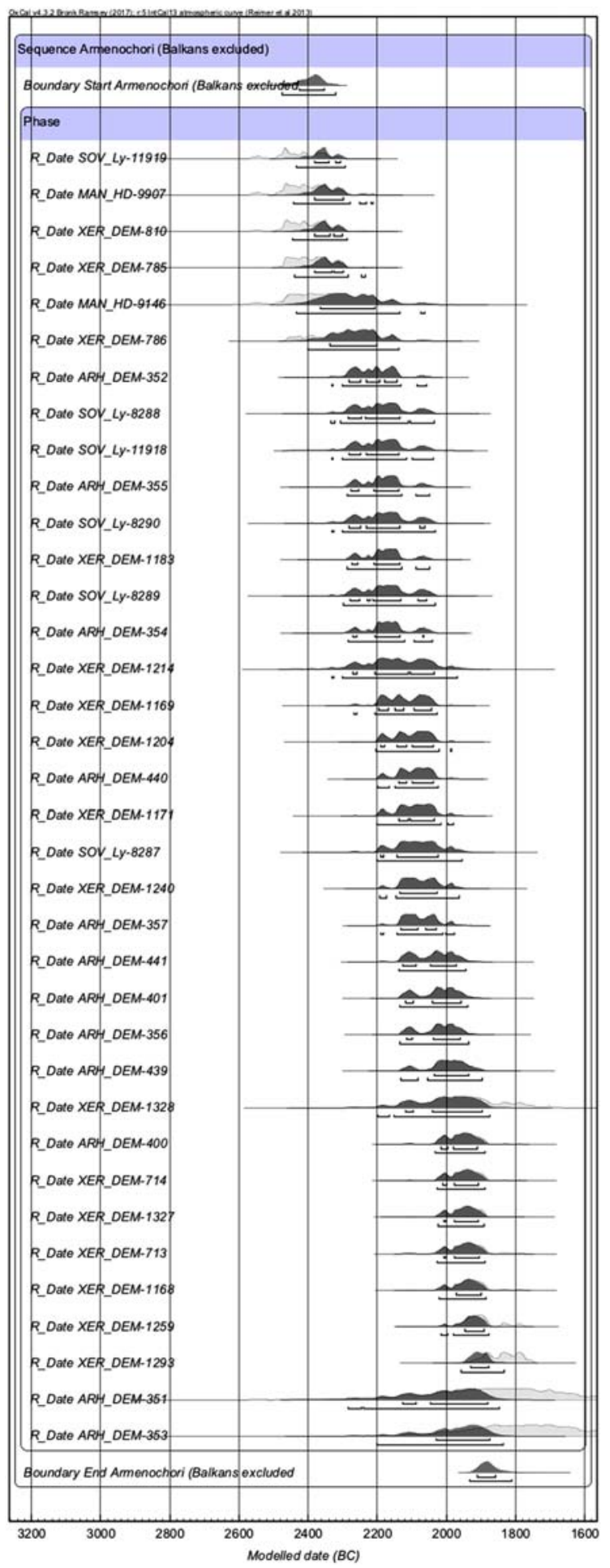

Figure 9 Bayesian modeling of ${ }^{14} \mathrm{C}$ dates for the Armenochori group in Greece, EBA 3, excluding Ranutovac (ARH = Archontiko, MAN $=$ Mandalo, SOV $=$ Sovjan, XER $=$ Xeropigado $)$. 


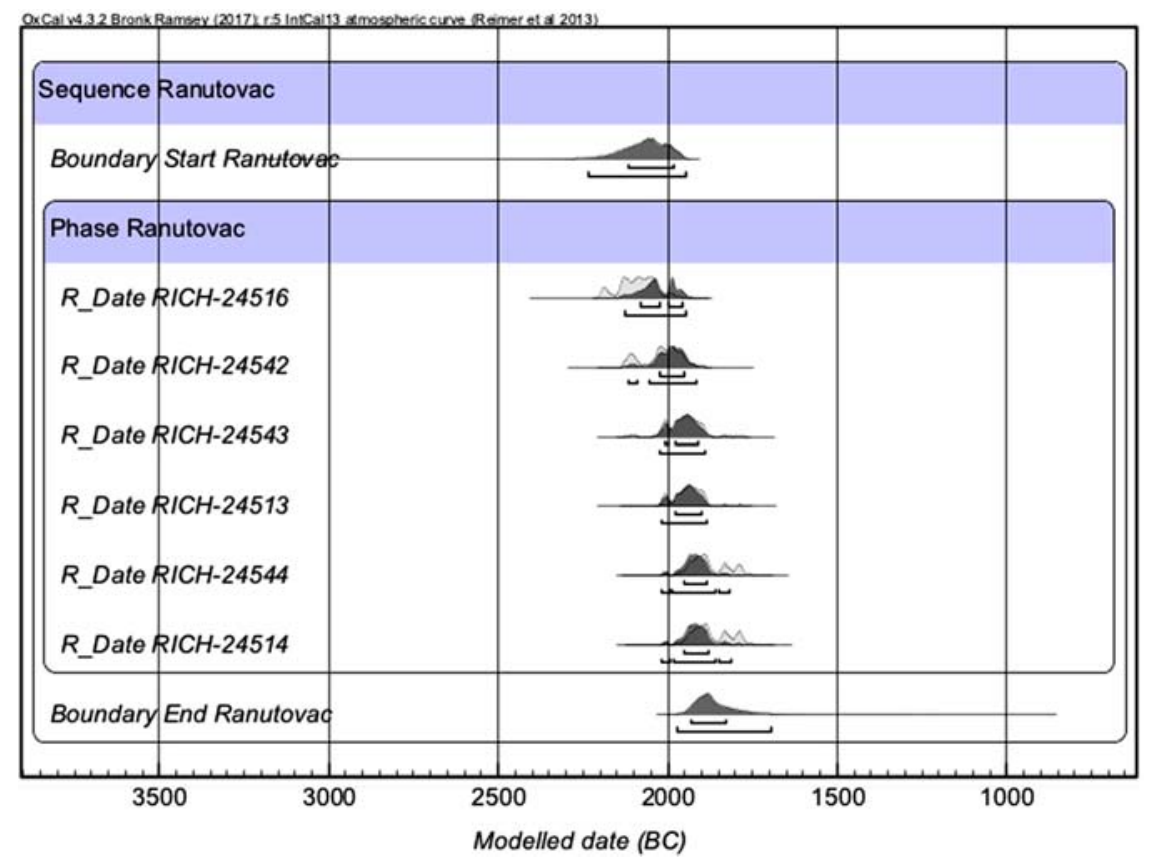

Figure 10 Bayesian modeling of ${ }^{14} \mathrm{C}$ dates for Ranutovac, EBA 3.

Using the "difference" function in OxCal to compare the start dates for this second model and the Ranutovac one (corresponding to the label Armenochori-central Balkans on Figure 10), it appears that the Ranutovac sequence begins with a delay of $244-400$ years $(68.2 \%$ probability) or $121-429$ years $(95.4 \%$ probability).

Although based on limited evidence, these results thus suggest that the Armenochori cultural group can be tentatively divided into two partially overlapping phases, and that it is possible to observe an expansion of Armenochori features from central Macedonian region towards the north (Hammond 1972: 240; Bulatović 2014: 68) along the upper stream of the South Morava River (Bulatović 2014: Map 2), the west (Gori 2020) and the south, towards the Chalkidiki Peninsula in its second phase in the last quarter of the 3rd millennium cal BC. The existence of two phases was already hinted at by typological and, in very few cases, stratigraphic evidences (e.g. Sovjan, Albania, Gori 2015a); however, it was never demonstrated with absolute chronological data. The results presented here, therefore, are particularly encouraging. Furthermore, ceramic assemblages suggest some relationship between both Cetina and Armenochori groups. Two-handled beakers from Cetina contexts show a combination of distinctive Cetina decorative traits with Armenochori typological features (e.g. double-handled vessels from Jukić; Olujić 2012: P1. 8; Bajagić; Govedarica 1989: Pl. XLVI/2; and Shtoj; Govedarica 1989: Pl. XXIX/1). Likewise, several vases found in Armenochori sites present features echoing Cetina and wider Aegean traditions (e.g. the pedestal-footed vessel from grave 2 at Ranutovac; Bulatović et al. 2016: Pl. I/5 that compares to Cetina examples from tumulus 2 at Shkrel, Albania Jubani 1995; Maran 2007: 15; Gori 2020).

The smoking pot/miniature oven model found by Tsountas (1908: 274, Figure 198) in the uppermost destruction levels at Sesklo is the southernmost known example of this type of 
object (Bulatović 2013; Gori 2015b), and together with the well-known presence of Cetina pottery in the Peloponnese at e.g. Olympia, Lerna, Andravida Lechaina, Teichos Dymaion (Gori et al. 2018), and ceramic features of southern origin in central Balkans (Gori 2015a, 2015b, 2020) it confirms that central and western Balkans were closely connected to Greece down to the Peloponnese.

The chronology of the eponymous site of Armenochori, excavated in the 1931 by Heurtley (1939: 57-59), has always posed problems (Hanschmann and Milojčić 1976: 212; Aslanis 1985: 278; Maran 1998: 106-107), as until recently it represented the only site whose ceramics connected the central Balkans to the Greek mainland. Despite new excavations, Armenochori stratigraphic and ceramic sequences remain regrettably unpublished except for a concise report (Chrysostomou 1998). Since several sites yielding Armenochori type ceramics have been excavated and published-including Archontiko (Merousis 2004), Mandalo (Papaefthymiou Papanthimou and Pilali Papasteriou 1997), Sovjan (Gori 2015a), Xeropigado (Ziota 1998), and Ranutovac (Bulatović et al. 2016) - this new information allows for a better understanding of the typological development of this group, which will require chronological elucidation through further ${ }^{14} \mathrm{C}$ sampling. Even though the definition of the Armenochori cultural group is no longer based on the Armenochori sequence, this name is maintained to avoid possible confusion. Typical ceramics for this group are double-handled beakers, referred to also as kantharoi, and smoking pots/miniature oven models.

Two-handled beakers group together vessels with a variety of morphologies ranging from open, shallow examples to deep, closed forms. Handle shape may also vary substantially. Two-handled beakers are known from an area extending from Transdanubia to continental Greece during a period spanning the 5th to 1 st millennium BC. The initial identification of the Armenochori group was based solely on the presence or absence of two-handled beakers, which, together with jars of "unfamiliar forms", characteristic plastic enhancement of tubular handles, and the near absence of bowls with incurving rims, convinced Heurtley to consider Armenochori separately from other sites discovered in Macedonia (Heurtley 1939: 85). Two-handled beakers are present also at sites belonging to Bubanj-Hum III, while in the Belotić-Bela Crkva assemblages there are no two-handled beakers that resemble Armenochori, Bubanj-Hum III or Maroš examples, but a variant of this shape with an elongated cylindrical, sometimes funnel shaped neck. Only one two-handled beaker, together with other finds characteristic for the BubanjHum III group (Figure 3/17-18), has been found at Ada in Prijevor (RICH 2450). Absolute dating shows that Ada belongs to a younger horizon with respect to BelotićBela Crkva burials. These data further hint at the chronological precedence of BelotićBela Crkva in respect to Bubanj-Hum III and Armenochori. Dates from Novačka Ćuprija (Nikolova 1999: 404: sample codes Beta 2572 and BC 84) where pottery partially matching with the stylistic and typological elements of the Bubanj-Hum III group was found, as well as new dates from Viminacium (Bulatović, Kapuran and Milovanović 2019) point to a possible expansion of the Bubanj-Hum III group towards north at the end of the 3rd millennium BC.

\section{CONCLUSIONS}

During the 3rd millennium BC, the Balkans were subdivided into a mosaic of overlapping networks with different ranges. For the early part of the $3 \mathrm{rd}$ millennium $\mathrm{BC}$, metal objects 


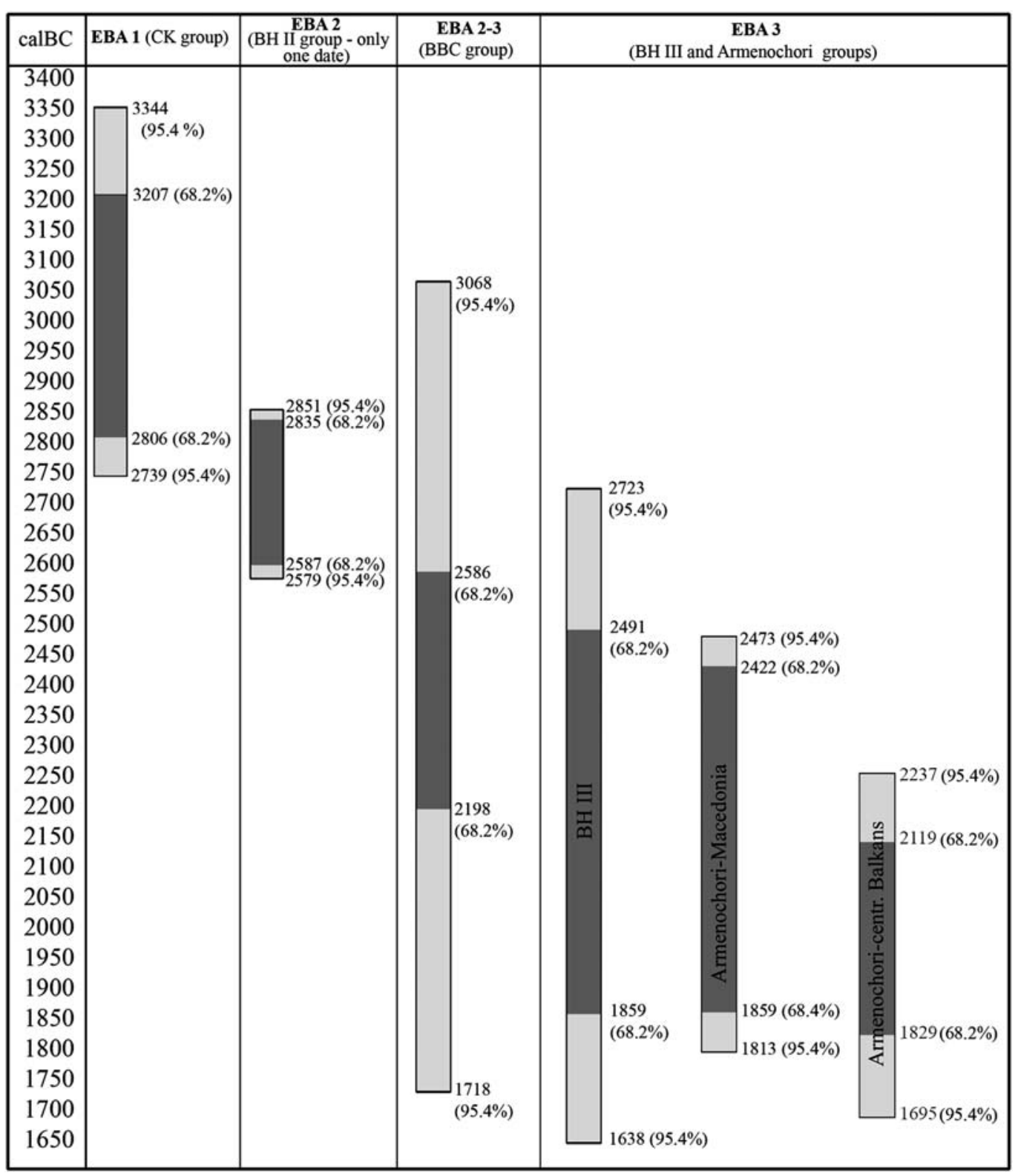

Figure 11 Chronological table for EBA in the central Balkans (Abbreviations for cultural groups: CK CotofeniKostolac; BH II - Bubanj-Hum II; BH III - Bubanj-Hum III; BBC - Belotić-Bela Crkva)

found in funerary assemblages of the south Adriatic Vučedol group provide the only evidence for long-distance networks connecting the Balkans to the Aegean and even Anatolia (Maran 2007). From the mid-3rd millennium BC onwards the Balkans were connected with the Central Mediterranean through supra-regional networks such as the Bell Beaker phenomenon (e.g. presence of Bell Beaker-related wrist-guards in several Dalmatian sites: Heyd 2007; Forenbaher 2018a; Gori 2020). Further examples of such extensive interaction comprising also the Aegean include the Cetina phenomenon, as well 
as the large-scale distribution of tankards with an oval body and cylindrical neck (typical of the Belotić-Bela Crkva) and two-handled beakers (the so-called Armenochori kantharoi) in funerary contexts found in an area extending from Transdanubia to continental Greece. At the end of the 3rd millennium $\mathrm{BC}$, there is an apparent increase in connectivity that crosslinked Central Mediterranean and Balkan networks, with emphasis on a north-south axis that crosses the Peninsula. In the central Balkans, a major difficulty in the identification and interpretations of the trajectories of such distant connections is in the lack of a solid chronological framework.

Through a combination of 25 new radiocarbon dates and re-examination of the existing documentation, this paper defines the absolute chronology for groups which were previously only broadly framed into the early 3rd millennium BC (Figure 11). These absolute dates have allowed us to establish with greater clarity the chronological relations between different cultural groups in the central Balkans. Yet, when comparing together the chronologies for material culture, funerary treatment of the body (i.e. inhumation, cremation) funerary architecture, there are no easily discernible patterns.

Available evidence points to the fundamental role of the funerary sphere as an area for social and cultural negotiations. For instance, the dates obtained in this study for western Serbia confirm that cremation and inhumation were used in conjunction in the Belotić-Bela Crkva group (EBA 2-3 ca. 2700-2100 cal BC), whilst the only inhumation was attested in EBA 1 (c. 3200-2800 cal BC).

We also reported the earliest dates for the Bubanj-Hum III group and for the two-handled beakers phenomenon in the central Balkans. Our dating programme and analysis confirms that the Armenochori and Bubanj-Hum III groups chronologically overlap during a significant part of the 3rd millennium cal BC (e.g. Maran 1998: 109-110). Although the Armenochori group is first observed in geographic Macedonia from the third quarter of 3rd millennium cal BC onwards, its influence, under the form of pottery traits, is not attested in the central Balkans until the end of the 3rd millennium cal BC.

Rather than a single area of origins for all traits, we observe a complex mix of traits crisscrossing over a wide area encompassing the Pannonian basin, the central Balkans and the Greek peninsula. Communities living in the Balkans during the end of the 4th and the 3rd millennium cal BC were entangled in a web of exchange and dynamic borrowing different cultural traits, the precise organization of which remains to be further described and explained.

\section{ACKNOWLEDGMENTS}

The authors are grateful to the Fritz Thyssen Foundation, which provided generous financial support to the project "Rewriting Early Bronze Age Chronology in the southwestern Balkans: Evidence from Large-Scale Radiocarbon Dating”. The analyses of the samples were undertaken at the CEZ Archäometrie gGmbH Laboratory in Mannheim, Germany (Dr. Ronny Friedrich), and at the KIK-IRPA, The Royal Institute for Cultural Heritage, Belgium (Dr. Mathieu Boudin). The authors want to thank the Institute for Preand Protohistory of the University of Heidelberg, which hosted the project and provided logistic support and M. Milinković for background of the map (Figure 1). We thank the anonymous reviewers for their careful reading of our manuscript and their many insightful comments and suggestions. 


\section{REFERENCES}

Alexandrov S. 2007. Bronze Age materials from Bagacina (North-West Bulgaria). In: Stefanovich M, Angelova C, editors. Prae, in honorem Henrieta Todorova. Sofia. p. 103-129.

Arvaniti T, Maniatis Y. 2018. Tracing the absolute time-frame of the Early Bronze Age in the Aegean. Radiocarbon 60(3):751-773.

Aslanis I. 1985. Kastanas, die Fruhbronzezeitlichen Funde und Befunde. Berlin. In German.

Asouhidou S. 2011. The Early Bronze Age burial mound at Kriaritsi-Sykia (Central Macedonia, Greece). In: Borgna E, Müller-Celka S, editors. Ancestral landscapes, burial mounds in the Copper and Bronze Ages (Central and Eastern Europe-Balkans-Adriatic-Aegean, 4th-2nd millennium B.C.). Proceedings of the International Conference held in Udine, May 15th-18th 2008. Lyon: Maison de 1'Orient et de la Méditerranée Jean Pouilloux. p. 383-90.

Bayliss A, Bronk Ramsey C, van der Plicht J, Whittle A. 2007. Bradshaw and Bayes: towards a timetable for the Neolithic. Cambridge Archaeological Journal 17(S1):1-28.

Benkö L, Horvath L, Horvatinčić N, Obelić B. 1989. Radiocarbon and thermoluminescence dating of prehistoric sites in Hungary and Yugoslavia. Radiocarbon 31(3):992-1002.

Bogdanović M. 1986, Љуљаци, насеље протоватинске и ватинске културе, Крагујевац. In Serbian.

Boyadziev Y. 1995. Chronology of prehistoric cultures in Bulgaria. In: Bailey DW, Panayotov I, editors. Prehistoric Bulgaria. p. 149-191.

Borić D. 2009. Absolute dating of metallurgical innovations in the Vinča Culture of the Balkans. In: Keinlin TL, Roberts BW, editors. Metalsand societes, studies in honour of Barbara S. Ottaway. Bonn: Habelt. p. 191-245.

Boudin M, Van Strydonck M, van den Brande T, Synal HA, Wacker L. 2015. RICH-A new AMS facility at the Royal Institute for Cultural Heritage, Brussels, Belgium. Nuclear Instruments and Methods in Physics Research B 361:120-123.

Breunig P. 1987. ${ }^{14}$ C-Chronologie des Vorderasiatischen, Südost- und Mitteleuropaischen Neolithikums. Köln. Fundarnenta, Reihe A, B and 13.

Bronk Ramsey C. 2009. Bayesian analysis of radiocarbon dates. Radiocarbon 51(1):337-360.

Broodbank C. 2013. The making of the Middle Sea: A history of the Mediterranean from the beginning to the emergence of the classical world. London.

Bulatović A. 2013. Oven models from Early Bronze Age settlements in central and southern parts of the Balkan peninsula. Archaeologia Bulgarica XVII, 1:1-13.

Bulatović A. 2014. New Finds as a contribution to the study of the Early Bronze Age in the southern part of the Central Balkans. Старинар н.c. LXIV:57-75.
Bulatović A. 2015. Енеолитски период на локалитету Мокрањске стене. In: Капуран А, Булатовић А, editors. Мокрањске стене, културна баштина Неготинске Крајине. Неготин: Музеј Неготинске Крајине. p. 33-49. In Serbian.

Bulatović A, Bizjak D, Vitezović S. 2016. Necropolis from the Early Bronze Age at the site Meaniste in Ranutovac near Vranje. In: Perić S, Bulatović A, editors. Archaeological investigations along the route of the E 75 Highway, 2011-2014. Belgrade: Institute of Archaeology. p. 71-89.

Bulatović A, Kapuran A, Milovanović B. 2019. Horizont ranog bronzanog doba na lokalitetu Rit/Early Bronze Age horizon at the site of Rit. In: Kapuran A, Bulatović A, Filipović V, Golubović S, editors. Viminacijum u praistoriji (Viminacium in Prehistory), Institute of Archaeology, Belgrade, p. 55-77. In Serbian and English.

Bulatović A, Milanović D. 2015. Велика хумска чука, истраживања 2009.године - прилог проучавању стратиграфије енеолита и бронзаног доба у југоисточној Србији.Гласник Српског археолошког друштва 30:163-88. In Serbian.

Bulatović A, Milanović D. 2020. Bubanj, the Eneolithic and the Early Bronze Age Tell in Southeastern Serbia. Vienna: MPK-Mitteilungen der Prähistorischen Kommission der Österreichischen Akademie der Wissenschaften.

Bulatović A, Stankovski J. 2012. Бронзано доба у басену Јужне Мораве и у долини Пчиње/ Бронзено време во басенот на Јужна Морава и долината на Пчиња. Belgrade: Kumanovo. In Serbian and Macedonian.

Bulatović A, Vander Linden M. 2017. Absolute dating of Copper and Early Bronze Age levels at the eponymous archaeological site Bubanj (southeastern Serbia). Radiocarbon 59(4): 1047-1065.

Bulatović A, Vander Linden M, Gori M. 2018. New absolute dates as contribution to the absolute chronology of the Early Eneolithic in the central Balkans. Starinar 68:19-32.

Chrysostomou Pan. 1998. Toumba Armenochoriou, The Prehistoric mound of Armenochori. In:

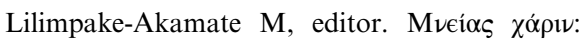

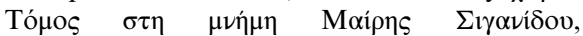
Thessaloniki: Ypourgeio Politismou. p. 335-353.

Ciugudean H. 1996. Perioada timpurie a epocii bronzului în centrul şi sud-vestul Transilvaniei, Bibliotheca Thracologica, XIII, Bucureşti. In Romanian.

Cvijić J. 1922. Балканско полуострво и јужнословенске земље. Belgrade. In Serbian.

Dimitrijević S. 1979. Zur Frage der Genese und der Gliederung der Vučedoler Kultur in dem Zwischenstromland Donau-Drau-Save. Vjesnik Arheološkog muzeja u Zagrebu Vol. 10-11, No.1 (1977/78):1-96. In German. 
Dmitrović K. 2002. Резултати археолошких истраживања праисторијске некрополе под хумкама на локалитету Руја у Дучаловићима. Зборник радова Народног музеја 32, Чачак:5-22. In Serbian.

Dmitrović K. 2016. Bronze Age necropolises in the Čačak region. National Museum, Čačak.

Dörpfeld W. 1927. Alt-Ithaka II, Zellner: Osnabrück.

Durman A, Obelić B. 1989. Radiocarbon dating of Vučedol cultural complex. Radiocarbon 31(3):1003-1009.

Forenbaher S. 1993. Radiocarbon dates and absolute chronology of the central European Early Bronze Age. Antiquity 67(255):218-256.

Forenbaher S. 2018a. Special place, interesting times. The island of Palagruža and transitional periods in Adriatic prehistory. Oxford: Archaeopress.

Forenbaher S. 2018b. Ljubljana and Cetina: Pottery styles of the third millennium BC in the eastern Adriatic. Prilozi Instituta za arheologiju $\mathrm{u}$ Zagrebu 35:113-158.

Forsén J 2012. Mainland Greece. In: Cline EH, editor. The Oxford handbook of the Bronze Age Aegean: (ca. 3000-1000 BC). Oxford: Oxford Univ. Press. p. 53-65.

Garašanin D. 1967. Periodizacija bronzanog doba Srbije. Materijali IV sa Kongresa arheologa Jugoslavije održanog u Herceg Novom 1966. Godine: 203-8. In Serbo-Croatian.

Garašanin M. 1957. Ausgrabungen in Bubanj bei Niš (Serbisches Moravagebiet). Germania 35(3-4): 198-207. In German.

Garašanin M. 1958a. Kontrollgrabung in Bubanj bei Niš.Praehistorische Zeitschrift XXXVI: 223-44. In German.

Garašanin M. 1958b. Ископавања на Бубњу код Ниша, претходни извештај за 1954-1956. годину. Старинар н. с. VII-VIII (1956-1957): 269-74. In Serbian.

Garašanin M. 1973. Праисторија на тлу Србије. Belgrade. In Serbian.

Garašanin M. 1983. Grupa Bubanj-Hum III. In: Benac A, editor. Praistorija jugoslavenskih zemalja IV, Sarajevo. p. 719-722. In SerboCroatian.

Garašanin M, Garašanin D. 1962. Ископавање тумула у комплексу Белотић-Бела Црква 1959. и 1960. године. Зборник радова Народног музеја III: 47-68. In Serbian.

Gogâltan F. 1999. Bronzul timpuriu şi mijlociu în Banatul românesc pe cursul inferior al Mureşului. Cronologia şi descoperirile de metal. Timişoara: Orizonturi Universitare. In Romanian.

Gori M. 2015a. Along the rivers and through the mountains. A reviewed chrono-cultural framework for the south-western Balkans during the late 3rd and early 2nd millennium BCE. Bonn: Habelt.

Gori M. 2015b. The long journey of a few ugly pots. Long distance cultural interactions in southwestern Balkans at the end of the Early Bronze Age. In: Suchowska-Ducke P, Scott Reiter S, Vandkilde H, editors. Forging identities. The mobility of culture in Bronze Age Europe. Oxford: BAR International Series, Archaeopress. p. 183-192.

Gori M. 2018. Bronze Age and the embedded Macedonian question. In: Gimatzidis $\mathrm{S}$, Pieniazek M, Mangaloğlu-Votruba S, editors. Archaeology across frontiers and borderlands. Fragmentation and connectivity in the North Aegean and the central Balkans from the Bronze Age to the Iron Age. Oriental and European Archaeology (OREA) 9. Vienna: Austrian Academy of Sciences. p. 391-410.

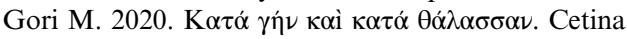
communities on the move across the Central Mediterranean and the Balkans in the 3rd millennium BC. In: Băjenaru R, Maran J, Alincăi SC, Hansen S, Popescu AD, editors. Objects, ideas and travelers. Contacts between the Balkans, the Aegean and western Anatolia during the Bronze and Early Iron Age. Proceedings, Conference in memory of A. Vulpe. Bonn: Habelt.

Gori M, Recchia G, Tomas H. 2018. Trans-Adriatic connections in the second half of the $3 \mathrm{rd}$ millennium BC: An international research project. In: Gravina A, editor. Atti del 38 Convegno Nazionale Preistoria e Protostoria della Daunia, S. Severo: 2017. p. 197-216.

Govedarica B. 1989. Rano bronzano doba na području istočnog Jadrana. Akademija Nauka i Umjetnosti Bosne i Hercegovine, Knjiga 67. Sarajevo. In Serbo-Croatian.

Govedarica B. 2006. Finds of the Cetina-type in the western Balkan hinterland and the issue of culture-historical interpretation in the prehistoric archaeology. Vjesnik za arheologiju i povijest dalmatinsku 99.1:27-41.

Hammond NGL. 1972. A History of Macedonia. Vol. I. Oxford.

Hanschmann E, Milojčić V. 1976. Die Deutschen Ausgrabungen auf der Argissa Magula in Thessalien, III. Die frühe und beginnende mittlere Bronzezeit. Bonn: Habelt. In German.

Heurtley WA. 1939. Prehistoric Macedonia. Cambridge.

Heyd V. 2007. When the West meets the East: The eastern periphery of the Bell beaker phenomenon and its relation with the Aegean Early Bronze Age. In: Galanaki I, Tomas H, Galanakis Y, Laffineur R, editors. Between the Aegean and Baltic Seas. Prehistory across borders. Proceedings of the International Conference Bronze and Early Iron Age Interconnections and Contemporary Developments between the Aegean and the Regions of the Balkan Peninsula, Central and Northern Europe, University of Zagreb, 11-14 April 2005. 
Aegaeum 27, Liège and Austin, Université de Liège, Histoire de l'art et archeologie de la Grèce antique and University of Texas at Austin, Program in Aegean Scripts and Prehistory. p. $91-104$.

Jovanović B. 1976. Obredi sahranjivanja u kostolačkoj grupi. Godišnjak Centra za balkanološka ispitivanja ANUBIH, knj. XIII:131-42. In Serbo-Croatian.

Jubani B. 1995. Kultura e bronzit të hershëm në tumat e Shkrelit. Iliria 25:57-70. In Albanian.

Jung R, Weninger B. 2015. Archaeological and environmental impact of the $4.2 \mathrm{ka}$ cal BP event in the central and eastern Mediterranean. In: Meller H, Arz HW, Jung R, Risch R, editors. $2200 \mathrm{BC}$ - ein Klimasturz als Ursache für den Zerfall der alten Welt: 7. Mitteldeutscher Archäologentag vom 23.bis 26. Oktober 2014 in Halle (Saale), Halle (Saale): Landesamt f. Denkmalpflege u. Archäologie Sachsen-Anhalt. p. 205-234.

Kalafatić H. 2006. A Vinkovci culture urn grave from the site at 40 Duga Ulica in Vinkovci. Prilozi Instituta za arheologiju u Zagrebu 23/2006:17-28.

Kapuran A, Bulatović A. 2012. Културна група Коцофени-Костолац на територији источне Србије, Старинар н.c. LXII:63-94. In Serbian.

Kapuran A, Bulatović A, Milanović D. 2018. Settlement pattern changes during the central Balkans Copper Age. In: Dietz S, Mavridis F, Trankosić $\check{Z}$, Takaoglou T, editors. Communities in transition: The circum-Aegean area in the 5th and 4th millennia BC. Oxbow. p. $77-88$.

Kilian-Dirlmeier I. 2005. Die bronzezeitlichen Gräber bei Nidri auf Leukas. Ausgrabungen von W. Dörpfeld 1903-1913, Mainz: Verl. des RömischGermanischen Zentralmuseums. In German.

Kromer B, Lindauer S, Synal H.A., Wacker L. 2013. A new AMS facility at the Curt-EngelhornCentre for Archaeometry, Mannheim, Germany. Nuclear Instruments and Methods in Physics Research B 294:11-3.

Krstić D, Bankoff A, Vukmanović M, Winter F. 1986. Праисторијски локалитет Новачка ћуприја. Зборник Народног музеја и Београду XII-1: 17-63. In Serbian.

Kulcsár G. 2009. The beginnings of the Bronze Age in the Carpathian basin. Budapest.

Kulcsár G. 2013. Glimpses of the third millenium BC in the Carpathian Basin. In: Anders A, Kulksár G, Kalla G, Kiss V, Szabó G, editors. Moments in time, papers presented to Pál Raczky on his 60th birthday. Budapest: L'Harmattan. p. 643-60.

Lazić M, Ljuština M. 2017. Поље у селу Глоговац вишеслојно праисторијско налазиште. In: Prodanovic Rankovic I, editor. Arheološka istraživanja na autoputu E80 = Archaeological Explorations at the E80 Highway, Belgrade. p. 126-57. In Serbian.
Lera P, Touchais G. 2004. Le Bronze Moyen dans le bassin de Korçë à la lumière des fouilles de Sovjan. In: Cabanes P, Lamboley JL, editors. L'Illyrie méridionale et l'Épire dans l'Antiquité IV, Act. coll. Grenoble, 10-12 Oct. 2002, 2004. p. 23-38. In French.

Leshtakov К. 1992. Изследования върху бронзовата епоха в Тракия I. сравнителна стратиграфия на селищните могили от ранната бронзова епоха в югоизточна България, Годишник на софийския университет „Св. Климент Охридски“ том 84-85, София: 5-119. In Bulgarian.

Maniatis Y, Kromer B. 1990. Radiocarbon dating of the Neolithic/Early Bronze Age site of Mandalo, W. Macedonia. Radiocarbon 32(2):149-153.

Maniatis Y, Ziota Ch. 2011. Systematic ${ }^{14} \mathrm{C}$ dating of a unique Early and Middle Bronze Age cemetery at Xeropigado Koiladas, West Macedonia, Greece. Radiocarbon 53(3):461-478.

Manning SW. 1995. The absolute chronology of the Aegean Early Bronze Age: Archaeology, radiocarbon and history. Sheffield: Sheffield Acad. Press.

Maran J. 1998. Kulturwandel auf dem griechischen Festland und den Kykladen im späten 3. Jahrtausend v. Chr., Teil I und II. Bonn: Habelt. In German.

Maran J. 2007. Seaborne contacts between the Aegean, the Balkans and the Central Mediterranean in the 3rd Millennium BC: The unfolding of the Mediterranean World. In: Galanaki I, Tomas H, Galanakis Y, Laffineur R, editors. Between the Aegean and Baltic Seas. prehistory across borders. Proceedings of the International Conference Bronze and Early Iron Age Interconnections and Contemporary Developments between the Aegean and the Regions of the Balkan Peninsula, Central and Northern Europe, University of Zagreb, 11-14 April 2005. Aegaeum 27, Liège and Austin, Université de Liège, Histoire de l'art et archeologie de la Grèce antique and University of Texas at Austin, Program in Aegean Scripts and Prehistory. p. 3-25.

Marović I. 1991. Istrazivanja kamenih gomila cetinske culture u srednjoj Dalmaciji, Vjesnik za arheologiju i historiju dalmatinsku 84:15-214. In Croatian.

Merousis N. 2004. Early Bronze Age in the Pella-Imathia plain, Western Macedonia. In: Alram-Stern E, Felten F, Efstratiou N, editors. Die Ägäische Frühzeit. Vienna: Verlag der Österreichischen Akademie der Wissenschaften. p. 1285-1295.

Müller Celka S. 2012. Burial mounds and "ritual tumuli" of the Aegean Early Bronze Age. In: Borgna E, Müller-Celka S, editors. Ancestral landscapes, burial mounds in the Copper and Bronze Ages (Central and Eastern EuropeBalkans-Adriatic-Aegean, 4th-2nd millennium B.C.). Proceedings of the International 
Conference held in Udine, May 15th-18th 2008. Lyon: Maison de 1'Orient et de la Méditerranée Jean Pouilloux. p. 415-428.

Nikitović L. 2003. Krstac-Ivkovo brdo, nekropola sa humkama iz bronzanog doba. In: Bojović N, Vasić M, editors. Sahranjivanje u bronzano i gvozdeno doba, Symposium held at Čačak in 2002, Čačak. p. 11-22. In Serbo-Croatian.

Nikolić D. 1997. Енеолитска насеља у околини Мајданпека. In: Лазић M, editor. Археологија Источне Србије, Центар за археолошка истраживања Филозофског факултета, Београд. p. 197-210. In Serbian.

Nikolova L. 1999. The Balkans in later prehistory, periodization, chronology and cultural development in the final Copper and Early Bronze Age (fourth and third millennia BC). BAR International Series 791.

Nikolova L, Görsdorf J. 2002. New radiocarbon dates from the Balkans (Dubene-Sarovka): approach to the early bronze absolute chronology in upper Thrace. Radiocarbon 44(2):531-40.

Olujić B. 2012. Istraživanja dvije kamene gomile na području Zagvozda (Imotski, Hrvatska)/ The Excavation of Two dry stone burial mounds in the Zagvozd Area (Imotski, Croatia). Opuscola Archaeologica 36:55-91.

Orsich-Slavetić A. 1940. Bubanj, eine Prähistorische Ansiedlung bei Niš, Mitteilungen der prähistorischen Kommission der Akademie Wissenchaften 1940:1-42. In German.

Papaefthymiou Papanthimou A, Pilali Papasteriou A.

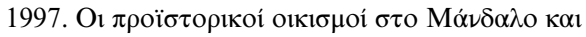

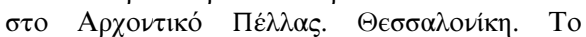

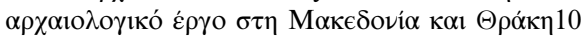
A:143-58. In Greek.

Pappa M. 2010. Die Nekropole der frühen Bronzezeit. In: Hänsel B, Aslanis I, editors. Das Prähistorische Olynth. Ausgrabungen in der Toumba Agios Mamas 1994-1996. Die Grabung und Baubefund. M. Leidorf: Rahden/ Westfalen. p. 382-440.

Reinecke P. 1902. Beiträge zur Kenntnis der frühen Bronzezeit Mitteleuropas. Mitteilungen der Anthropologischen Gesellschaft Wien 32:104-154. In German.

Roman P. 2006. Preuves concernant les mouvements ethno-culturels de l'est á l'ouest et du sud au nord, dans la haute période de l'age du bronze, résultées des recherches faites á Ostrovul Corbului. In: Tasić N, Grozdanov C, editors. Homage to Milutin Garašanin, Belgrade. p. 455-468. In French.

Rutter J B. 2001. Review II: The Prepalatial Bronze Age of the southern and central Greek mainland. In: Cullen $\mathrm{T}$, editor. Aegean prehistory: A review. Boston: Archaeological Institute of America. p. 95-155.
Snoeck C, Brock F, Schulting RJ. 2014. Carbon exchanges between bone apatite and fuels during cremation: Impact on radiocarbon dates. Radiocarbon 56:591-602.

Stojić M. 1996. Le Bassin de la Morava a l'age de bronze et a la periode de transition de l'age de bronze a celui de fer. In: Tasić N, editor. The Yugoslav Danube basin and the Neighboring Regions in the 2nd millennium B.C. Symposium, Vršac, October 11-14, 1995. On the occasion of the year of the Bronze Age-the First Golden Age of Europe, Initiative of Council of Europe, Archaeological Heritage, Belgrade-Vršac. p. 247-256. In French.

Stojić M, Nikitović L. 1996. Ada in Prijevor bei Čačak-Beitrag zur der Bronzezeit im Moravagebiet und im serbischen Donaugebeit. Starinar 47:205-212. In German.

Tasić N. 1979. Coţofeni kultura. In: Benac A, editor. Praistorija jugoslovenskih zemalja III. Sarajevo. p. 115-28. In Serbo-Croatian.

Tasić NN, Tasić N. 2003. Serbian prehistoric archaeology in the 1990s. State of research. In: Grammenos DV, editor. Recent research in the prehistory of the Balkans. Thessaloniki: Archaeological Institute of Northern Greece. p. 73-128.

Todorova H. 2003. Prehistory of Bulgaria. In: Grammenos DV, editor. Recent research in the prehistory of the Balkans. Thessaloniki: Archaeological Institute of Northern Greece. p. 257-328.

Trajkovska L. 1995. Рано бронзено светилиште кај селото Пелинце. In: Таневски Б, editor. Каталог изложбе, Народни музеј у Куманову. In Macedonian.

Trajkovska L. 2003. Светилиште од раното бронзено доба на лок."Градиште" во село Пелинце кај Куманово. Пирајхме 2, Куманово:289-97. In Macedonian.

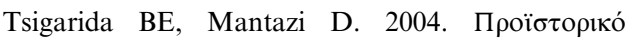

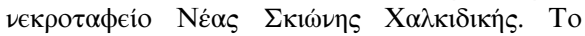

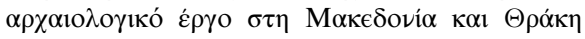
18:149-155. In Greek.

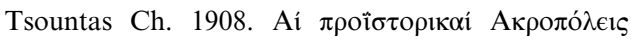
$\Delta \varkappa \mu \eta \operatorname{liov}_{\kappa} \alpha \imath \Sigma \varepsilon \dot{\varepsilon} \kappa \lambda$ ov, Athens. In Greek.

van Dommelen P, Knapp AB. 2010. Material connections in the ancient Mediterranean: Mobility, materiality and identity. Oxford: Routledge.

Van Strydonck M, Boudin M, De Mulder G. 2009. ${ }^{14} \mathrm{C}$ dating of cremated bones: the issue of sample contamination. Radiocarbon 51(2): 553-568.

Van Strydonck M, van der Borg K. 1990-1991. The construction of a preparation line for AMStargets at the Royal Institute for Cultural Heritage, Brussels. Bulletin Koninklijk Instituut voor Kunstpatrimonium 23:228-234. 
Velušček A, Čufar K. 2014. Pile dwellings at Ljubljansko Barje. In: Tecco-Hvala S, editor. Studia praehistorica in honorem Janez Dular. Opera Instituti Archaeologici Sloveniae 30. Ljubljana: Inštitut za arheologijo Znanstvenoraziskovalnega. p. 39-64. In Slovenian.

Wiencke MH. 2000. Lerna: A preclassical site in the Argolid, Volumes IV.1 and IV.2. The
Architecture, stratification, and pottery of Lerna III. Princeton: The American School of Classical Studies at Athens.

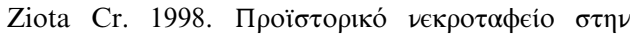

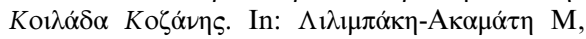

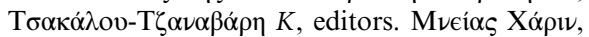

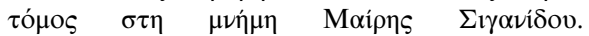
Thessaloniki. p. 81-99. In Greek. 